\title{
ASEAN+3 BOND MARKET GUIDE
}

\section{CAMBODIA}




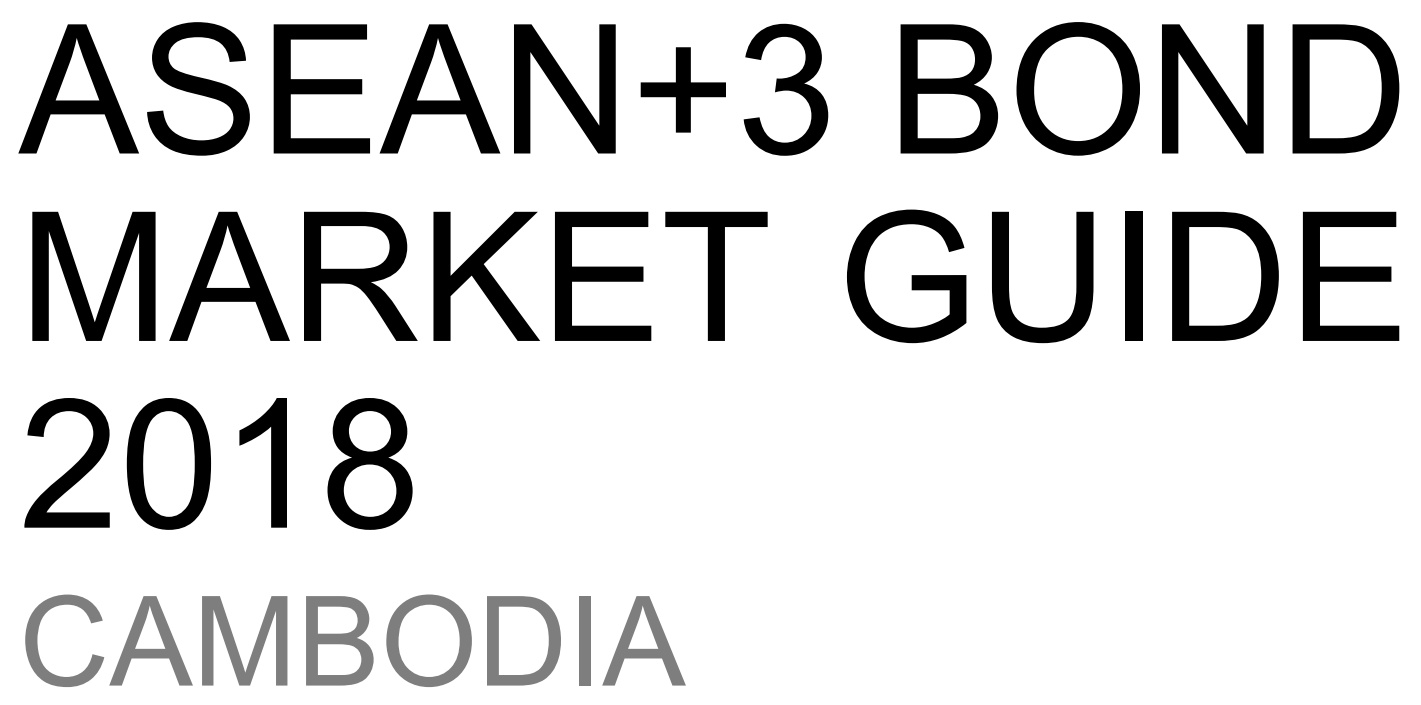




\section{Creative Commons Attribution 3.0 IGO license (CC BY 3.0 IGO)}

(C) 2018 Asian Development Bank

6 ADB Avenue, Mandaluyong City, 1550 Metro Manila, Philippines

Tel +632632 4444; Fax +6326362444

www.adb.org

Some rights reserved. Published in 2018.

ISBN 978-92-9261-066-1 (print), 978-92-9261-067-8 (electronic)

Publication Stock No. TCS189196-2

DOI: http://dx.doi.org/10.22617/TCS189196-2

The views expressed in this publication are those of the authors and do not necessarily reflect the views and policies of the Asian Development Bank (ADB) or its Board of Governors or the governments they represent.

ADB does not guarantee the accuracy of the data included in this publication and accepts no responsibility for any consequence of their use. The mention of specific companies or products of manufacturers does not imply that they are endorsed or recommended by ADB in preference to others of a similar nature that are not mentioned.

By making any designation of or reference to a particular territory or geographic area, or by using the term "country" in this document, ADB does not intend to make any judgments as to the legal or other status of any territory or area.

This work is available under the Creative Commons Attribution 3.0 IGO license (CC BY 3.0 IGO) https://creativecommons.org/licenses/by/3.0/igo/ By using the content of this publication, you agree to be bound by the terms of this license. For attribution, translations, adaptations, and permissions, please read the provisions and terms of use at https://www.adb.org/terms-use\#openaccess

This CC license does not apply to non-ADB copyright materials in this publication. If the material is attributed to another source, please contact the copyright owner or publisher of that source for permission to reproduce it. ADB cannot be held liable for any claims that arise as a result of your use of the material.

Please contact pubsmarketing@adb.org if you have questions or comments with respect to content, or if you wish to obtain copyright permission for your intended use that does not fall within these terms, or for permission to use the ADB logo.

Notes:

Corrigenda to ADB publications may be found at http://www.adb.org/publications/corrigenda

ADB recognizes "Korea" as the Republic of Korea.

In this report, international standards for naming conventions-International Organization for Standardization (ISO) 3166 for country codes and ISO 4217 for currency codes-are used to reflect the discussions of the ASEAN+3 Bond Market Forum to promote and support implementation of international standards in financial transactions in the region. ASEAN+3 comprises the Association of Southeast Asian Nations (ASEAN) plus the People's Republic of China, Japan, and the Republic of Korea.

The economies of ASEAN+3 as defined in ISO 3166 include Brunei Darussalam (BN; BRN); Cambodia (KH; KHM); the People's Republic of China (CH; CHN); Hong Kong, China (HK; HKG); Indonesia (ID; IDN); Japan (JP; JPN); the Republic of Korea (KR; KOR); the Lao People's Democratic Republic (LA; LAO); Malaysia (MY; MYS); Myanmar (MM; MMR); the Philippines (PH; PHL); Singapore (SG; SGP); Thailand (TH; THA); and Viet Nam (VN; VNM). The currencies of ASEAN+3 as defined in ISO 4217 include the Brunei dollar (BND), Cambodian riel (KHR), Chinese renminbi (CNY), Hong Kong dollar (HKD), Indonesian rupiah (IDR), Japanese yen (JPY), Korean won (KRW), Lao kip (LAK), Malaysian ringgit (MYR), Myanmar kyat (MMK), Philippine peso (PHP), Singapore dollar (SGD), Thai baht (THB), and Vietnamese dong (VND). 


\section{Contents}

Tables and Figures v v

Foreword vi vi vals

Acknowledgments vii

Abbreviations viii

I. Overview 1

$\begin{array}{lr}\text { A. Introduction } & 1\end{array}$

B. Financial Sector Development Strategy 2

C. Cooperation within the ASEAN Framework 2

II. Legal and Regulatory Framework 3

A. Legal Tradition 3

B. English Translation 3

C. Legislative Structure 3

D. Cambodian Financial and Capital Market Regulatory Structure 9

E. Regulatory Framework for Debt Securities 12

F. Debt Securities Issuance Regulatory Processes 12

G. Continuous Disclosure Requirements in the Cambodian Market 21

H. Self-Regulatory Organizations in the Cambodian Market 22

I. Approval, Licensing, and Accreditation of Market Participants 23

J. Cambodia Securities Exchange Regulations Related to Listing,
Disclosure, and Trading of Securities

K. Market Entry Requirements (Nonresidents) 25

L. Market Exit Requirements (Nonresidents) 25

M. Regulations and Limitations Relevant for Nonresidents 26

N. Regulations on Credit Rating Agencies $\quad 26$

III. Characteristics of the Cambodian Bond Market 28

A. Definition of Securities $\quad 28$

$\begin{array}{ll}\text { B. Types of Bonds and Notes } & 28\end{array}$

C. Money Market Instruments $\quad 29$

D. Methods of Issuing Debt Securities (Primary Market) 29

E. Governing Law and Jurisdiction (Securities Issuance) 31

F. Language of Documentation and Disclosure Items 31

G. Registration of Debt Securities 32

H. Listing of Securities $\quad 32$

I. Methods of Trading Securities (Secondary Market) 34

J. Securities Pricing 34

K. Transfers of Interest in Bonds and Notes $\quad 35$

L. Market Participants 36

M. Public Investor and Qualified Investor Concepts 40

N. Credit Rating Requirements $\quad 42$

O. Market Features for Investor Protection 42

P. Bondholders Representative 43

Q. Bankruptcy and Insolvency Provisions 44 
R. Event of Default $\quad 44$

IV. Bond and Note Transactions and Trading Market Infrastructure 46

A. Overview 46

B. Permitted Securities Market(s) 46

C. Trade Reporting 48

$\begin{array}{ll}\text { D. Market Monitoring } & 48\end{array}$

E. Information on Securities $\quad 48$

V. Description of the Securities Settlement System 50

VI. Bond Market Costs and Taxation 51

A. Costs Associated with Securities Issuance 51

B. Costs for Listing of Securities $\quad 52$

C. Ongoing Costs for Issuers of Securities $\quad 53$

D. Costs for Deposit and Withdrawal of Securities 53

E. Costs Associated with Securities Trading 53

F. Taxation Framework and Requirements 53

G. Tax Incentives $\quad 55$

$\begin{array}{ll}\text { VII. Market Size and Statistics } & 57\end{array}$

VIII. Presence of an Islamic Bond Market $\quad 58$

IX. Cambodian Bond Market Challenges and Opportunities 59

A. Challenges in the Cambodian Bond Market $\quad 59$

B. Opportunities in the Cambodian Bond Market 61

X. Recent Developments and Future Direction 63

A. Recent Major Developments 63

B. Future Direction $\quad 64$

Appendixes

1 Practical References $\quad 66$

2 List of Laws and Regulations $\quad 67$

3 Glossary of Technical Terms 69 


\section{Tables and Figures}

Tables

2.1 Examples of Securities Market Legislation by Legislative Tier . .4

2.2 Authorities Involved in Regulatory Processes by Issuer Type ........................ 13

4.1 Cambodia Securities Exchange-Trading Hours ...................................... 47

6.1 Duties and Taxes on Securities in Cambodia ............................................ 54

\section{Figures}

2.1 Prakas on the Securities and Exchange Commission of Cambodia Website ....8

2.2 Information Disclosure Process for Listed Companies in Cambodia ............... 22

3.1 Daily Securities Prices on the Cambodia Securities Exchange Website ........ 34

4.1 Information on the Cambodia Securities Exchange Website ...........................49 49 


\section{Foreword}

The Asian Development Bank (ADB) is working closely with the Association of Southeast Asian Nations (ASEAN) and the People's Republic of China, Japan, and the Republic of Korea-collectively known as ASEAN+3-to develop local currency bond markets and facilitate regional bond market integration under the Asian Bond Markets Initiative to strengthen the resilience of the region's financial systems.

Thanks to the efforts of member governments, local currency bond markets in ASEAN, the People's Republic of China, and the Republic of Korea have grown rapidly, with the total outstanding amount of bonds reaching more than USD10 trillion in 2016. Despite this remarkable development, intraregional investment in bond markets has remained subdued. As ADB has estimated that developing Asia will need to invest USD26 trillion from 2016 to 2030 (or USD1.7 trillion per year) in infrastructure for its continued growth, it is critical to mobilize the region's vast savings for the enormous investment needs. As an essential platform for such resource mobilization, the financial markets in ASEAN+3 need to be more harmonized and integrated. Also, the regional efforts should support developing member countries at early stages of market development.

The ASEAN+3 Bond Market Forum (ABMF) was established with the endorsement of the ASEAN+3 Finance Ministers in 2010 as a common platform to foster the standardization of market practices and harmonization of regulations relating to crossborder bond transactions in the region. As an initial step, ABMF published the ASEAN+3 Bond Market Guide in 2012, which was welcomed as the first official information source offering a comprehensive explanation of the region's bond markets.

Since publication of the ASEAN+3 Bond Market Guide, bond markets in the region have continued to develop. ABMF recognizes the need for revisions to the guide to reflect these changes, though it is never an easy task to keep up with rapid changes in the markets. This report is an outcome of the strong support and kind contributions of ABMF members and experts, particularly from Cambodia. The report should be recognized as a collective good to support bond market development among ASEAN+3 members. It is our hope that the revised ASEAN+3 Bond Market Guide will facilitate further development of the region's bond markets, contribute to increased intraregional bond transactions, and promote efficient allocation of capital within the region.

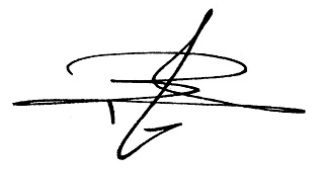

Yasuyuki Sawada

Chief Economist and Director General

Economic Research and Regional Cooperation Department 


\section{Acknowledgments}

The ASEAN+3 Bond Market Guide was first published in 2012 as the initial output of Phase 1 of the ASEAN+3 Bond Market Forum (ABMF). ${ }^{1}$ In addition to an update of the original 11 jurisdictions' bond markets guides, 3 new markets were taken up this time. Across the region, economies with nascent domestic bond markets, including Cambodia, have experienced tremendous development over the past 5 years. ${ }^{2}$ Now in Phase 3, ABMF would like to share, in the public domain, information on these developments by publishing a Cambodia Bond Market Guide for the first time.

The ABMF Sub-Forum 1 team-comprising Satoru Yamadera (Principal Financial Sector Specialist, Asian Development Bank, Economic Research and Regional Cooperation Department); Kosintr Puongsophol (Financial Sector Specialist, Asian Development Bank, Economic Research and Regional Cooperation Department); and Asian Development Bank consultants Shigehito Inukai and Matthias Schmidt-would like to stress the significance and magnitude of the contributions made by ABMF national members and observers for Cambodia, including the National Bank of Cambodia and the Securities and Exchange Commission of Cambodia. These policy bodies and regulatory authorities generously gave their time for market visit meetings, discussions, and follow-up. They have also reviewed and provided inputs on the draft Cambodia Bond Market Guide over the course of ABMF Phase 3.

The ABMF team also would like to express its thanks to the market institutions and professional firms who so kindly hosted the team during the initial market visit, including the Ministry of Economy and Finance of Cambodia, Cambodia Securities Exchange, Yuanta Securities (Cambodia) Plc., SBI Royal Securities Plc, and HBS Law Firm. In this context, special thanks go to CIMB Bank PLC in Cambodia and Nomura Research Institute, who contributed their time and expertise in support of the market visits and specific topics of discussion.

No part of this report represents the official views or opinions of any institution that participated in this activity as an ABMF member, observer, or expert. The ABMF SubForum 1 team bears sole responsibility for the contents of this report.

December 2017

ASEAN+3 Bond Market Forum

\footnotetext{
${ }^{1}$ ASEAN +3 refers to the 10 members of the Association of Southeast Asian Nations (ASEAN) plus the People's Republic of China, Japan, and the Republic of Korea.

${ }^{2}$ The Asian Development Bank recognizes Cambodia as the Kingdom of Cambodia.
} 


\section{Abbreviations}

\begin{tabular}{|c|c|}
\hline ABMF & ASEAN+3 Bond Market Forum \\
\hline ACMF & ASEAN Capital Markets Forum \\
\hline ADB & Asian Development Bank \\
\hline ASEAN & $\begin{array}{l}\text { Association of Southeast Asian } \\
\text { Nations }\end{array}$ \\
\hline ASEAN+3 & $\begin{array}{l}\text { Association of Southeast Asian } \\
\text { Nations plus the People's Republic of } \\
\text { China, Japan, and the Republic of } \\
\text { Korea }\end{array}$ \\
\hline CRA & credit rating agency \\
\hline CSX & Cambodia Securities Exchange \\
\hline IFRS & $\begin{array}{l}\text { International Financial Reporting } \\
\text { Standards }\end{array}$ \\
\hline GDNT & $\begin{array}{l}\text { General Department of National } \\
\text { Treasury }\end{array}$ \\
\hline KHR & Cambodian riel (ISO code) \\
\hline MEF & Ministry of Economy and Finance \\
\hline NBC & National Bank of Cambodia \\
\hline OTC & over-the-counter \\
\hline RTGS & real-time gross settlement \\
\hline SECC & $\begin{array}{l}\text { Securities and Exchange Commission } \\
\text { of Cambodia }\end{array}$ \\
\hline SF1 & Sub-Forum 1 of ABMF \\
\hline SRO & self-regulatory organization \\
\hline USD & United States dollar \\
\hline
\end{tabular}




\section{Overview}

\section{A. Introduction}

In 2012, Cambodia published a Financial Sector Development Strategy (FSDS) for the period 2011-2020 (see also section B). Among the long-term development objectives contained in the strategy that were targeted for implementation between 2017 and 2020 was a focus on developing the government securities market and the issuance of government bonds by the Government Debt Management Office of the National Treasury. As an initial milestone of this development plan, the Cambodia Securities Exchange (CSX) had previously been established in 2010. The National Bank of Cambodia began issuing negotiable certificates of deposit in 2013, effectively creating an interbank money market.

Fundamental legislation and key legislation for the securities market came into effect in 2007 with the adoption of the Law on Government Securities and the Law on the Issuance and Trading of Non-Government Securities. The Securities and Exchange Commission of Cambodia (SECC) was inaugurated in 2008 as an autonomous regulatory authority. Since then, the SECC has been gradually establishing the necessary regulatory framework and practices for a corporate bond market. The CSX has been operating since 2010 and features comprehensive listing rules. While the present listings are limited to equities, it is expected that the CSX will allow the listing and trading of debt securities as well.

The regulatory framework now supports the definition of Qualified Investors, a concept that may give rise to a professional market segment once debt securities issuance, listing, and trading commences. The SECC published the initial set of necessary Prakas (official declarations) for the corporate bond market in August 2017 and is further detailing definitions and procedural requirements for corporate bonds, with the corresponding regulations expected by early 2018 .

At present, no real-time gross settlement (RTGS) system exists and payments are typically made via cheque. However, the National Bank of Cambodia (NBC) has introduced the Online Banking System for cheque payments among commercial banks that are members of the Online Bank System. The policy bodies and regulatory authorities recognize the need for capacity building across the nascent industry.

All securities listed and traded on the CSX are already and exclusively created in the electronic book-entry system of the CSX Depository. Although the early stage of relevant regulations referred to the possible issuance of securities in both electronic and certificate form, the SECC's policy has been to use electronic form only to be in line with international best practice and as a convenience for investors and intermediaries alike.

Because of the nascent stage of the Cambodian bond market, the Cambodia Bond Market Guide is expected to be updated on a regular basis to adequately report on the 
significant developments expected in the market, including the issuance of corporate and government bonds and subsequent debt securities listings on the CSX.

\section{B. Financial Sector Development Strategy}

In 2012, the Government of Cambodia issued the FSDS for the period 2011-2020 as a publication of the Asian Development Bank (ADB), which supported its compilation. ${ }^{1}$ The strategy was adopted by the Council of Ministers on 25 November 2011.

Subsequently, the FSDS was updated to reflect the policy objectives for 2016-2025. This latest version of the FSDS was officially launched on 15 June 2017 and includes development objectives such as: ${ }^{2}$

- a primary dealer concept,

- comprehensive open market operation of the NBC,

- creation of a spot market under the NBC, and

- further definition of the securities market under the guidance of the SECC.

The report identified achievements, challenges, and an action plan for each subsector and the financial sector as a whole for the indicated period, divided into short-term, medium-term, and long-term strategies and objectives. A number of these achievements, challenges, and plans specific to the bond market and the capital market at large are presented in the relevant chapters of the Cambodia Bond Market Guide.

\section{Cooperation within the ASEAN Framework}

In addition to their contribution to the Association of Southeast Asian Nations (ASEAN) Economic Community plans, the Cambodian policy bodies and regulatory authorities, particularly the SECC, participate in a range of ASEAN and ASEAN+3 initiatives in the bond market and the overall capital market.

Key among those are the ASEAN+3 Bond Market Forum (ABMF), which focuses on the development of local currency bond markets in the region-both through regulatory initiatives and the standardization or harmonization of market practicesand the ASEAN Capital Markets Forum (ACMF). ACMF has been working on a number of regional policy initiatives, recently summarized in the ACMF Vision 2025. ${ }^{3}$ Among these initiatives, the ACMF Action Plan, 2016-2020 contains the ACMF Market Development Programme, which will be a common platform to coordinate capacity building programs and efforts to optimize resources and avoid duplication of programs, with a particular focus on Cambodia, the Lao People's Democratic Republic, Myanmar, and Viet Nam. ADB is a partner of ACMF in these efforts.

\footnotetext{
${ }^{1}$ ADB. Kingdom of Cambodia Financial Sector Development Strategy, 2011-2020. http://adb.org/sites/default/files/pub/2012/financial-sector-development-strategy-2011-2020.pdf ${ }^{2}$ For details of the FSDS, please refer to https://www.nbc.org.kh/download_files/publication/blueprints_eng/Financial-Sector-Development-Strategy2016-2025-English.pdf

${ }^{3}$ For a PDF download of the ACMF Vision 2025, please refer to http://www.theacmf.org/ACMF/upload/acmfactionplan2016-2020.pdf
} 


\section{Legal and Regulatory Framework}

\section{A. Legal Tradition}

Cambodia's legal system follows the civil law tradition.

Many of the relevant laws and regulations for the securities market have been putin place since the late 1990s and continue to be revised and adjusted to the requirements of modern financial and capital markets.

\section{B. English Translation}

Cambodia does not have an official requirement to translate legislation into English. Instead, the respective regulatory authorities often take it upon themselves to provide an unofficial English version of applicable laws and regulations to the market at large. This may lead to differences in interpretation of the original Khmer version. At the same time, translations undertaken by the SECC are generally referenced as consistent in the use and definition of English technical terms for the securities industry.

While the English translation of Cambodian laws and regulations find frequent use, they may only be used for reference since the final interpretation-and the acceptance and application by Cambodian courts-is based on the original Khmer version.

\section{Legislative Structure}

Like many ASEAN+3 economies, Cambodia features a multitiered legislative and regulatory system, both overall and for the securities market in particular, guided by the Constitution of the Kingdom of Cambodia.

The tiered approach is detailed below using the designated Khmer terms and the example of existing securities market-related legislation and regulations.

[1st tier] Constitution of the Kingdom of Cambodia

[2nd tier] Kram (laws or decrees) represent both fundamental and key legislation

[3rd tier] Anukret (sub-decrees) are intended to detail laws and decrees for a particular area of legislation such as for securities market-related implementation rules and regulations

[4th tier] Prakas (official declarations) represent further detailed implementation rules under the respective Anukret [5th tier] Guidelines from regulatory authorities 
Table 2.1 applies the prevalent legislation and regulations to the individual tiers of the legislative structure for the securities market mentioned above.

Table 2.1: Examples of Securities Market Legislation by Legislative Tier

\begin{tabular}{|c|c|}
\hline Legislative Tier & Content or Significant Examples \\
\hline $\begin{array}{l}\text { Constitution of the Kingdom of } \\
\text { Cambodia }\end{array}$ & Principles, Rights, and Obligations \\
\hline $\begin{array}{l}\text { Fundamental legislation: Kram (laws } \\
\text { or decrees) } \\
\text { and } \\
\text { Key legislation for the securities } \\
\text { market }\end{array}$ & $\begin{array}{l}\text { - Law on State-Owned Enterprises, } 1996 \\
\text { - } \quad \text { Law on the Organization and Conduct of the } \\
\text { National Bank of Cambodia, } 1997 \\
\text { - } \quad \text { Law on Banking and Financial Institutions, } 1999 \\
\text { - } \quad \text { Law on Commercial Enterprises, } 2005 \\
\text { - Government Securities, } 2007 \\
\text { - Law on Government Securities, } 2007\end{array}$ \\
\hline $\begin{array}{l}\text { Implementation rules and regulations: } \\
\text { Anukret (sub-decrees) }\end{array}$ & $\begin{array}{l}\text { - Anukret on the Conduct and Organization of the } \\
\text { Securities and Exchange Commission of } \\
\text { Cambodia, } 2008 \\
\text { Anukret on the Implementation of the Law on the } \\
\text { Issuance and Trading of Non-Government } \\
\text { Securities, } 2009 \\
\text { Anukret on Tax Incentives in the Securities } \\
\text { Sector, } 2015\end{array}$ \\
\hline Prakas (official declarations) & $\begin{array}{l}\text { Prakas on the Licensing of Securities Firms and } \\
\text { - } \quad \text { Pecurities Representatives, } 2009 \\
\text { the NBC, } 2010 \\
\text { - } \quad \text { Prakas on Code of Conduct of Securities Firms } \\
\text { and Securities Representatives, } 2011 \\
\text { - } \quad \text { Prakas on Qualified Investors in the Securities } \\
\text { Sector, } 2016 \\
\text { - Prakas on Operating Rules on Securities } \\
\text { - } \quad \text { Piquidity Provider, } 2016 \\
\text { Rules of Securities Market, } 2017 \\
\text { - Prakas on Accreditation of Professional } \\
\text { Accounting Firm Providing Professional Services } \\
\text { in the Securities Sector, } 2017 \\
\text { Prakas on Public Offering of Debt Securities, } \\
2017 \\
\text { - Prakas on Accreditation of Credit Rating Agency, } \\
2017 \\
\text { Prakas on Accreditation of Bondholders } \\
\text { Representative, } 2017\end{array}$ \\
\hline Guidelines & $\begin{array}{l}\text { - Guidelines on Granting Investor Identification } \\
\text { Number, } 2012 \\
\text { Guidelines on Application Forms to Open a } \\
\text { Trading Account and Customer Agreements for } \\
\text { Derivatives Trading, } 2016\end{array}$ \\
\hline
\end{tabular}

NBC $=$ National Bank of Cambodia.

Source: Compiled by ADB consultants for SF1 and based on publicly available information. 


\section{Legislation: Kram (laws or decrees)}

Fundamental legislation consists of basic laws or decrees that may govern the issuance of specific instruments and the basic roles and responsibilities of financial and securities market participants. These laws and decrees are reviewed and updated through the full legislative process, requiring tabling by the Prime Minister in (and adoption by) the National Assembly, approval by the Senate, and promulgation by the King before taking effect.

Key legislation is the summary term or important additional term for those laws or decrees aimed at a certain market or specific activities, such as the bond market or the securities market at large.

\section{Fundamental Legislation}

The Law on Commercial Enterprises, 2005 represents the foundation for the issuance of securities-both equity and debt-in Cambodia. However, the law does not contain a universal definition of securities. In addition, Cambodia also features the Law on State-Owned Enterprises, 1996, which specifies the actions and responsibilities of state-owned enterprises across all market activities, including the issuance of securities.

At the same time, the Law on Banking and Financial Institutions, 1999 defined a number of original activities for banks and financial institutions relating to the securities market when such a market was still to be established.

Together, these laws have formed the basic legal framework for securities issuance and many market participants for some time.

\section{a. Law on Commercial Enterprises, 2005}

The Law on Commercial Enterprises, 2005 replaced the governance of activities within and among companies that had previously been done purely on a contractual basis. The law defines and prescribes roles and responsibilities, as well as actions for commercial enterprises, including private partnerships and limited public companies.

The law states the ability and criteria for commercial enterprises to issue securities, but this law does not provide details on the procedures to issue securities.

For those companies making a public offering of securities, the relevant activities fall under the Law on Trading and Issuance of Non-Government Securities, 2007, which is reviewed later in this section.

\section{b. Law on State-Owned Enterprises, 1996}

The Law on State-Owned Enterprises, 1996 states the types, roles, and responsibilities of state-owned enterprises, including their possible activities as permitted entities in the securities market. State-owned enterprises are likely to eventually participate in the securities market, as both issuers and investors, once the bond market commences operation. 


\section{Key Legislation}

Key legislation for the bond market and the securities market at large in Cambodia consists of two specific laws, one with a focus on government securities and the other on nongovernment securities.

\section{a. Government Securities_Law on Government Securities, 2007}

The principal basis for the issuance of government securities is the Law on Government Securities, 2007. However, this law has not yet been fully implemented since the issuance of government securities is only targeted to begin in 2019. In order to implement this law effectively, the Ministry of Economy and Finance (MEF) is drafting an Anukret (sub-decree) on government securities issuance.

In addition, the actual issuance of government securities for each fiscal year may in future be regulated by the Financial Management Law for the respective fiscal year.

\section{b. Nongovernment Securities_Law on the Issuance and Trading of Non- Government Securities, 2007}

The Law on the Issuance and Trading of Non-Government Securities, 2007 remains the key piece of legislation for the securities market in Cambodia. The law provided for the establishment of the SECC and provided for the role and functions of a securities exchange, securities clearing and settlement operator, and securities depository operator. It also gave the SECC authority to license securities firms and identify the basic roles and responsibilities of other specific market participants.

\section{Anukret (Implementation Rules and Regulations)}

In the Cambodian legislative context, an Anukret (used both in singular and plural form) further defines and details the corresponding laws and decrees with a focus on a particular area, in this context the bond and securities markets or market segments, its institutions, and participants. An Anukret is adopted by the Council of Ministers and signed by the Prime Minister.

Three existing Anukret deserve specific mention for the purpose of the bond market and the securities market at large.

\section{a. Anukret on the Implementation of the Law on the Issuance and Trading of Non-Government Securities, 2009}

This Anukret supports the implementation of the Law on the Issuance and Trading of Non-Government Securities, 2007. The procedures and criteria for the issuance of publicly issued securities of commercial enterprises are stated in this Anukret. In addition, the Anukret also regulates operators, including the securities market operator, clearing and settlement facility operator, and securities depository operator, all of which must comply with specific criteria to gain approval from the SECC, as well as the functions and obligations of each operator. Financial intermediaries-such as securities firms, collective investment schemes, and other financial services suppliers-are regulated by the SECC and need to obtain relevant licenses to operate their services. 


\section{b. Anukret on the Conduct and Organization of the Securities and Exchange Commission of Cambodia, 2008}

As the name suggests, this Anukret details the set-up, roles, and responsibilities of the SECC.

\section{c. Anukret on Tax Incentives in the Securities Sector, 2015}

The Anukret on Tax Incentives in the Securities Sector was introduced to the securities market in 2011 to encourage the issuance of securities among domestic companies and to attract both local and foreign investors. The incentives focus on equity and debt securities issued through a public offering and listed on a permitted securities market.

This Anukret was rolled over in 2015 as a measure to continue supporting the public issuance of securities and as an incentive for public investors to participate in the securities market. Equity and/or corporate bond issuers will be granted a tax incentive in the form of a reduction of $50 \%$ of the total amount of tax on profit to be paid, as well as a tax reduction of the withholding tax for securities investors for 3 years after listing. Public investors will also get a $50 \%$ deduction of the withholding tax on interest and/or dividends, which applies for a period of 3 years after the Anukret comes into force.

At the time of compilation of the Cambodia Bond Market Guide, the MEF was in the early stages of drafting an Anukret for the issuance of government securities, pursuant to the Law on Government Securities, 2007 and in line with the necessary preparations for the government's target to begin issuing securities by 2019 .

\section{Prakas (Official Declarations)}

Prakas (used both in singular and plural form) represent ministerial or inter-ministerial decisions signed by the minister overseeing the respective activities to be governed. Prakas must conform to the Constitution and to the law or sub-decree to which they refer, and are the equivalent of implementation rules and regulations issued by, for example, the MEF or the NBC. Prakas interpret aspects from key legislation such as the roles and responsibilities of market institutions and its participants. For the purpose of implementing and executing key legislation (Kram and Anukret), many individual Prakas may be issued.

Prakas to be issued for the securities market are proposed by the SECC and undergo inter-departmental review as well as consultations with related parties before being made available for public consultation. The results of the consultations and the proposed final Prakas are then presented to the SECC Board for approval before sending them to the minister for signature and promulgation.

In Cambodia, each Anukret pursuant to a particular area of legislation is complemented by a number of Prakas. Prakas with relevance for the securities market are available on the SECC and CSX websites (Figure 2.1); however, a number of Prakas, in particular those with operational details, might only be available in Khmer.

CSX rules are published as annexes to Prakas issued by the SECC. These rules govern specific aspects of the exchange business such as listing, membership, and market operation, and are enforced by the SECC.

One of the most recent Prakas was the Prakas on Qualified Investors in the Securities Sector (No. 005/2016 SECC/Pr.K.) issued in August 2016. The Prakas introduced a 
professional investor concept with Institutional Investors and High Net-Worth Investors as sub-categories. Please see Chapter III.N for details.

Figure 2.1: Prakas on the Securities and Exchange Commission of Cambodia Website

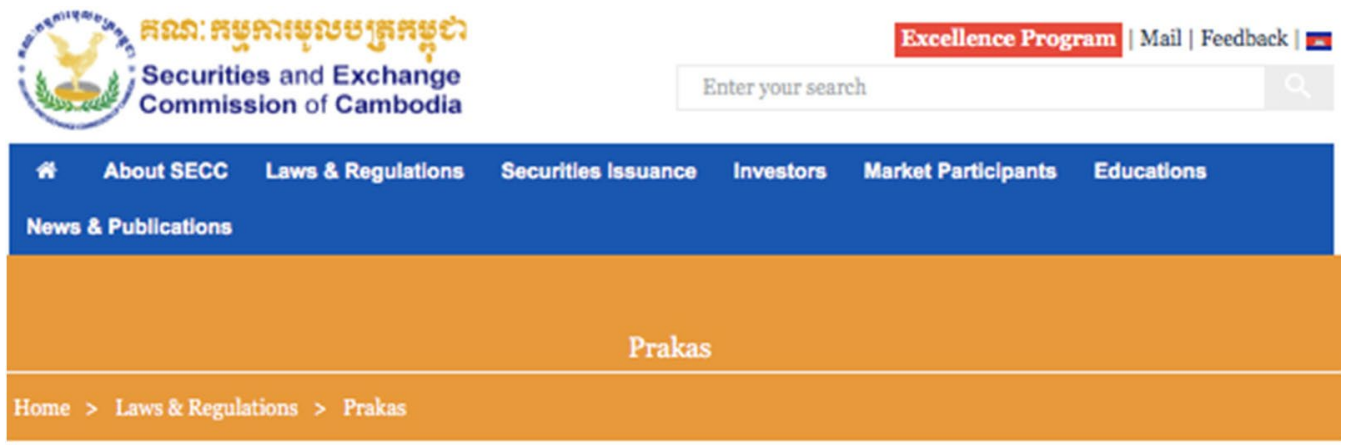

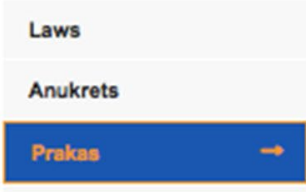

Orders \& Guidelines

Other Rules Regulation

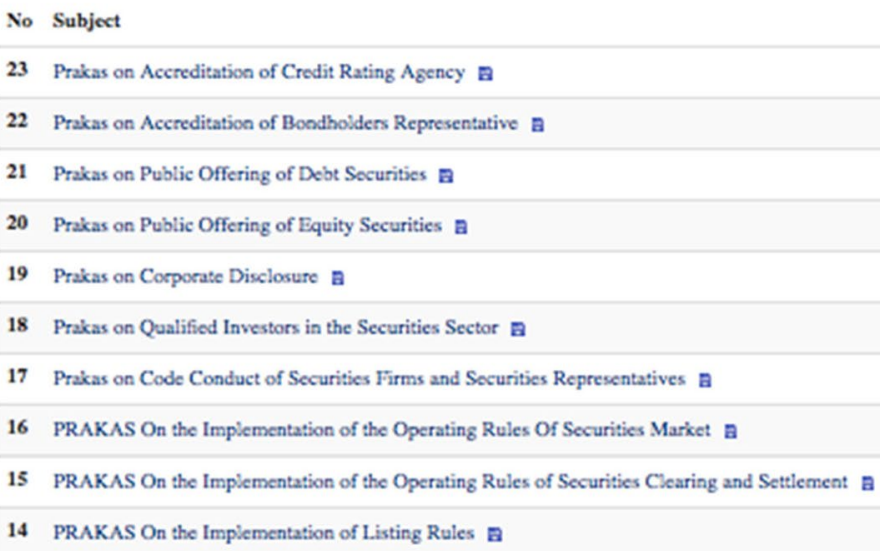

[1] 23

Source: Securities and Exchange Commission of Cambodia. Prakas. http://www.secc.gov.kh/english/m23.php?pn=3

After extensive public consultations, the SECC introduced a set of Prakas for the corporate bond market in August 2017, which included the Prakas on Public Offering of Debt Securities, the Prakas on Accreditation of Credit Rating Agency, and the Prakas on Accreditation of Bondholders Representative, pursuant to the Anukret on the Law on the Issuance and Trading of Non-Government Securities, 2007. The Prakas contain a definition of corporate bonds and permitted bond types, and detail the issuance application process and disclosure and documentation requirements to be met and the eligibility criteria and official prescriptions for credit rating agencies (CRAs) and bondholders representatives and their activities in the Cambodian market.

In a next step, the SECC will publish Prakas featuring the corresponding amendments to CSX rules to include or accommodate corporate bonds in the listing, disclosure, market operation, and settlement and depository activities. These Prakas are expected to be promulgated by early 2018 . 


\section{Guidelines}

The regulatory authorities also issue orders and guidelines on specific subjects under their purview, such as the SECC for matters related to the securities market. While guidelines are not legally binding, in contrast with Anukret and Prakas, they are issued under the executive powers of the SECC (or the respective authority) and are followed by the relevant constituents. The guidelines contain descriptions on how regulations should be applied and how specific market activities should be carried out.

In order to support the securities market, some guidelines are introduced to streamline the process of issuing and trading securities. These guidelines include the Guidelines on Book-Building and Subscription of Equity Securities, Guidelines on the Procedure of Cash Settlement in the Securities Market, Guidelines on the Mechanism of Initial Public Offering on Equity Securities, Guidelines on the Mechanism of Receiving a Securities Order, Guidelines on Dividend Payout to Shareholders for a Listed Company or Listed Public Enterprise, and Guidelines on Granting an Investor Identification Number, among others. However, these guidelines were issued to administer the issuing and trading of equity securities only. Once the regulatory framework for the corporate bond market has been fully established, new guidelines to support this market may be issued.

A list of relevant guidelines issued by the SECC can be found in Appendix 2.

\section{Cambodian Financial and Capital Market Regulatory Structure}

The key policy body for legislation, regulations, and the development of the financial and capital market, and the securities market at large, has traditionally been the MEF. In addition, the SECC, as the specific regulatory authority for the securities market, governs the activities of the participants in the bond market as detailed in this section.

\section{Ministry of Economy and Finance}

The MEF obtained its present mission under Anukret No. 04/ANK/BK to guide and administer the economy and finances of the Kingdom of Cambodia to support economic development and improve the living standards of the Cambodian people based on the principles of a free market economy and social equality. ${ }^{6}$

Among its specific tasks, MEF is to participate in developing, administering, and controlling industrial and financial activities, including insurance, market, bonds, lotto games, lotteries, casinos, retirement funds, and other financial reserves.

At the MEF, the General Department of Financial Industry is responsible for development of the government bond market. ${ }^{7}$ While the General Department of Financial Industry is not pursuing a particular bond issuance timeline-this was set by the General Department of National Treasury (GDNT) —its Financial Market Division is tasked with creating the prerequisites for a future government bond market; the immediate focus of the division is the creation of a suitable legislative environment and capacity building.

For the roles and responsibilities of the departments of the MEF in the context of issuance and issuance methods for government securities, please see Chapter III.

\footnotetext{
${ }^{6}$ See http://www.mef.gov.kh/about-ministry.html

${ }^{7}$ See http://gdfi.mef.gov.kh
} 


\section{General Department of National Treasury}

The GDNT, in operation since January 1991, is the single cashier and public accountant of the Government of Cambodia. The GDNT is responsible for Cambodia's public debt and plays a role in the formulation and execution of public finance-related policies, as well as the management of the public budget.

For the purposes of the capital market, the department's duties and tasks include the managing of government finances, including the future use of Treasury bills and government bonds.

\section{National Bank of Cambodia}

The NBC was established in December 1954, following the independence of Cambodia from France. The present legal basis for its operation is the Law on the Organization and Conduct of the National Bank of Cambodia, 1997.

As the central bank, the NBC is responsible for setting and executing monetary policy and conducting related activities. The NBC also regulates and supervises banks and financial institutions, including in the interbank market, and oversees the country's payment systems. ${ }^{8}$

Cambodia does not practice the universal banking system in which banks can actively participate in the securities and capital market under a single banking license. In addition, the Law on the Issuance and Trading of Non-Government Securities, 2007 confers the responsibility of the regulation and governance of the nongovernment securities market, as well as the secondary market for government securities, to the SECC.

\section{Securities and Exchange Commission of Cambodia}

The SECC was inaugurated on 23 July 2008 as a result of relevant provisions in the Law on the Issuance and Trading of Non-Government Securities, 2007.

The SECC is an autonomous government agency and the sole regulator of the securities sector in Cambodia, including infrastructure providers, market participants, and intermediaries for participant activities in the securities market. Due to the absence of government securities issuance until 2019, the SECC's present focus is on the stock (exchange) market and the building of a corporate bond market.

The SECC consists of a board with eight commissioners, plus the Minister of Economy and Finance as Chairman. Commissioners represent a number of government ministries and include persons with securities industry experience who are proposed by the MEF. The board answers to the MEF.

Chapter 2, Article 7 of the Law on the Issuance and Trading of Non-Government Securities, 2007 delineates the authority of the SECC as described below:

i. regulate and supervise securities markets, both government and nongovernment, in the Kingdom of Cambodia;

ii. enforce policy with respect to the securities market;

iii. formulate conditions for granting approvals to the operators of a securities market, clearance and settlement facility, and securities depository;

\footnotetext{
${ }^{8}$ For a complete description of the NBC's functions and duties, please refer to http://www.nbc.org.kh/English/about_the_bank/overview_of_functions_and_opertation.php
} 
iv. formulate conditions for granting licenses to securities companies and securities company representatives;

v. promote and encourage compliance with the requirements of this law, play a role as an institution to examine and solve complaints against, and consult with any qualified person to develop policies for the purpose of developing a securities market in the Kingdom of Cambodia; and

vi. fulfil other duties prescribed by sub-decree.

According to the law, details on the organization and functioning of the SECC were to be provided by an Anukret. The respective Anukret on the Conduct and Organization of the Securities and Exchange Commission of Cambodia (No. 97 ANKR.BK) was passed on 23 July 2008. The Anukret further details the functions and structure of the SECC, describing its departments and their main focus areas; it also contains an SECC organization chart as an appendix. ${ }^{9}$

Out of the six departments and one unit of the SECC (there is an additional, independent Internal Audit Unit as well), the following departments have direct responsibilities and oversight functions for the bond or securities market (with the relevant article of the Anukret provided):

- Department of Research, Training, Securities Market Developmentand International Relations (Article 7);

- Department of Securities Issuance Supervision (Article 8);

- Department of Securities Market Supervision (Article 9);

- Department of Securities Intermediaries Supervision (Article 10); and

- Department of Legal Affairs (Article 11).

Among its fundamental functions, the Department of Research, Training, Securities Market Development and International Relations conducts studies and researches strategies for developing the securities market in the Kingdom of Cambodia as well as the legal infrastructure and regulations relating to the supervision and development of the securities industry.

For the issuance of instruments in the Cambodian securities market, the Department of Securities Issuance Supervision examines and makes recommendations on public offerings of securities, in particular the registration statement and disclosure documents, the registration of these disclosure documents, and other statements of public issuing firms. The department also monitors and publishes any disclosure documents and other statements relating to the securities business made through electronic systems and/or the public media.

The Department of Securities Market Supervision is charged with formulating regulations, granting approval for operators of securities markets, managing the clearing and settlement facility, and supervising the securities depository. The granting of accreditation to market participants includes cash settlement agents, securities registrars or transfer agents, and paying agents. The department is also charged with the oversight of market trends and collecting various information, as well as the examination of suspicious transactions-such as suspected market manipulation, insider trading, or fraud-to ensure fair trading and to protect public investors.

In turn, the Department of Securities Intermediaries Supervision formulates regulations, grants licenses, and supervises securities firms and their representatives, securities dealers and securities brokers, fund managers, and other market participants and their operations.

\footnotetext{
${ }^{9}$ For the full text of the Anukret and the organization chart, please see http://www.cambodiainvestment.gov.kh/content/uploads/2011/09/Sub-Decree-97-on-the-Conduct-andOrganization-of-the-SECC.pdf
} 
Part of the remit of the Department of Legal Affairs is to examine and make recommendations on rules for operators of the securities market, develop and propose amendments to the rules and regulations, enforce the implementation of laws and regulations, receive any lawsuits and investigations related to illegal securities activities, undertake mediation and dispute resolution efforts among market participants, and file lawsuits and send them to the courts.

\section{E. Regulatory Framework for Debt Securities}

The MEF is in the early stages of drafting an Anukret for the issuance of government securities, while the SECC is the entity to draft relevant regulations for corporate bond issuance.

In the primary market, the issuance of and practices for government securities are regulated by the MEF. Nongovernment securities, including corporate bonds, are regulated by the SECC. To date, the relevant regulatory framework for nongovernment securities (corporate bonds) has been established through the publication of the Prakas on Public Offering of Debt Securities, Prakas on Accreditation of Bondholders Representative, and Prakas on Accreditation of Credit Rating Agency. This means that the regulatory framework for the primary market in corporate bonds is now ready for application. Operating rules for corporate bonds-such as rules on debt securities listing, market operation, clearing and settlement, and depository processes-are on track to be in place by early 2018 .

In the secondary market, both government securities and nongovernment securities (corporate bonds) are regulated by the SECC. The SECC also promulgates regulations for the trading, clearing, and settlement of debt securities in the Cambodian market. This includes any revisions to CSX rules, which are typically published as annexes to individual Prakas by the SECC.

\section{F. Debt Securities Issuance Regulatory Processes}

The provisions of the Law on the Issuance and Trading of Non-Government Securities, 2007 and related Anukret and Prakas contain fundamental provisions for the public offering of securities - with no distinction made between equities and debt securitiesbut also make allowance for exempt offers and provide a basic definition of private placements.

In August 2017, the SECC started setting specific regulatory processes for the issuance of nongovernment debt securities (corporate bonds) via a public offering and the related prescriptions for the appointment of a CRA and bondholders representative for such issuances.

It is expected that the SECC will further specify the processes for the offers of debt securities through private placements, including distinctions from public offerings in the issuance documentation and disclosure information.

At present, market practices, including the listing of securities, are focused on public offerings. In turn, the CSX, with the approval of the SECC, is expected to set dedicated rules for the listing (including profile listing) of debt securities, or to extend the existing listing rules to debt securities, as the case may be, by early 2018 .

1. Regulatory Processes by Issuer Type 
Table 2.2 provides an overview of these regulatory processes by issuer type and identifies which regulatory authority or market institution will be involved. In order to make the issuance process by issuer type more comparable across ASEAN+3 markets, the table features common issuer type distinctions that are evident in regional markets. Not all markets will distinguish all such issuer types or prescribe approvals. Sovereign issuers are typically exempt from corporate bond issuance approvals but, at the same time, may be subject to different regulatory processes.

Table 2.2: Authorities Involved in Regulatory Processes by Issuer Type

\begin{tabular}{|l|c|c|c|}
\hline Type of Issuer & SECC & NBC & $\begin{array}{c}\text { CSX } \\
\text { (listing only) }\end{array}$ \\
\hline Resident issuer & $X$ & $X$ & $X$ \\
\hline Resident nonfinancial institution & $X$ & $X$ & $X$ \\
\hline Resident financial institution & $X$ & & \\
\hline $\begin{array}{l}\text { Resident issuing FCY-denominated debt } \\
\text { securities }\end{array}$ & & & \\
\hline $\begin{array}{l}\text { Nonresident issuer } \\
\text { Nonresident nonfinancial institution }\end{array}$ & & & \\
\hline Nonresident financial institution & & & \\
\hline $\begin{array}{l}\text { Nonresident issuing FCY-denominated debt } \\
\text { securities }\end{array}$ & & & \\
\hline
\end{tabular}

CSX = Cambodia Securities Exchange, FCY = foreign currency, NBC = National Bank of Cambodia, SECC $=$ Securities and Exchange Commission of Cambodia.

Source: ADB consultants for SF1.

The table reflects the current regulatory regime, which requires approval for the issuance of nongovernment (corporate) debt securities from the SECC and a separate listing approval from the CSX for debt securities to be listed. According to the (Draft) Prakas on Listing Criteria of Banking and Financial Institutions on Cambodia Securities Exchange to be published by the NBC, banks and financial institutions supervised by the NBC are required to seek NBC approval prior to issuing and listing debt securities (see section 5 for details).

Nonresident issuers are presently not (yet) able to issue bonds and notes—or securities in general-in Cambodia, regardless of the issuance currency.

\section{Regulatory Process Overview}

The regulatory framework for the issuance of nongovernment (corporate) debt securities introduced by the SECC in August 2017 presently only covers issuance via a public offering and stipulates the need for an application process and approval from the SECC, including the registration of the disclosure document by the SECC upon successful application. The issuance of corporate bonds is closely linked to the listing and subsequent trading of the debt securities on the CSX, starting with the need foran issuer to obtain confirmation of listing eligibility of the proposed debt securities as one input item required for the issuance application to the SECC. 
The regulatory process map shown in Figure 2.2 provides an overview of the regulatory processes introduced for the Cambodian bond market. At the same time, based on existing mentions in laws and regulations, the regulatory processes for public offerings and private placements differ in one aspect; a public offering requires approval from the SECC, while the issuer only needs to file relevant documents with the SECC in the case of a private placement. However, only the regulatory process for public offerings has been described in detail by the SECC and, hence, its necessary steps are explained in the next few sections.

Figure 2.2: Regulatory Process Map—Nongovernment Debt Securities Issuance via Public Offering in Cambodia

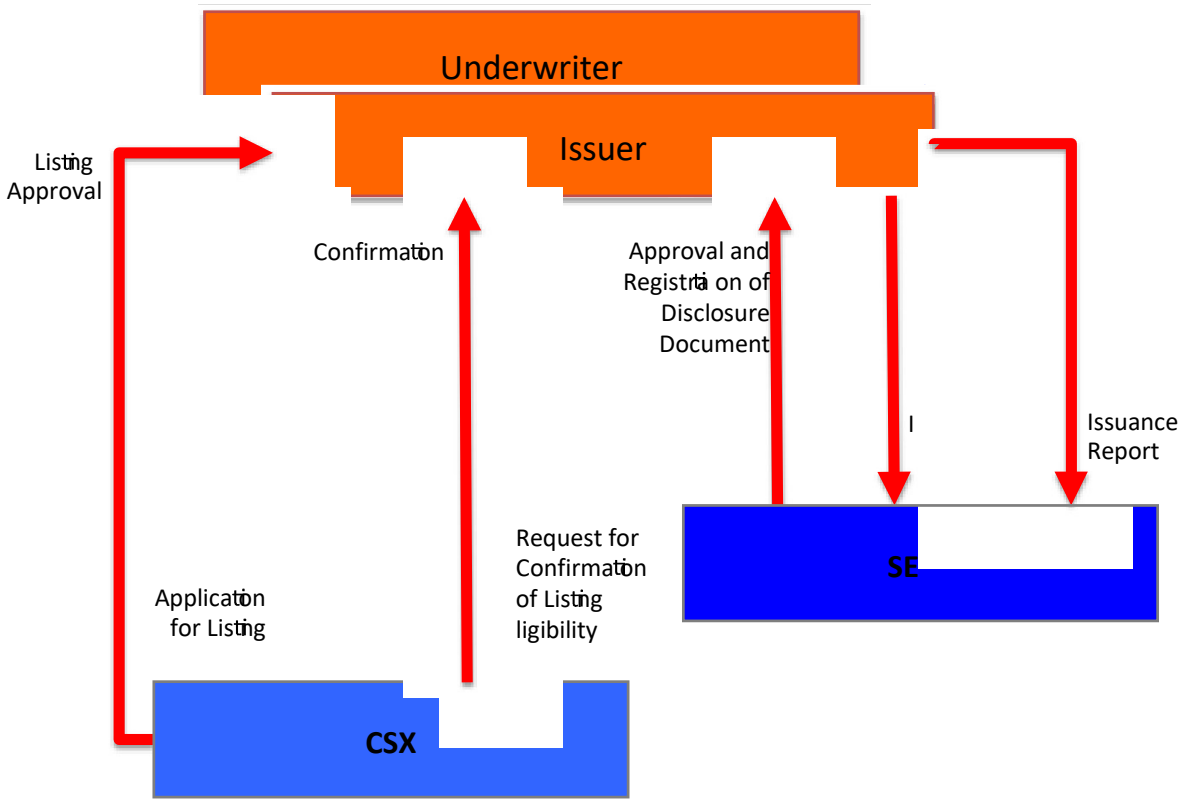

CSX = Cambodia Securities Exchange, SECC $=$ Securities and Exchange Commission of Cambodia Source: ADB consultants for SF1.

\section{Regulatory Process in Case of a Nonresident Issuer}

In the absence of specific provisions in Kram or Prakas for the securities market, nonresident are not yet able to issue debt securities in the Cambodian market.

\section{Regulatory Process for Public Offerings}

The regulatory framework for the issuance of corporate debt securities in Cambodia is focused on the issuance of instruments via a public offering, followed by a listing on the CSX. The regulatory process for private placements closely follows the one for public offerings described here (see also section 5). Corporate debt securities are subject to issuance approval from the SECC and, subsequently, listing approval from the CSX. 
The issuer needs to appoint an underwriter licensed by the SECC, who is also required to conduct due diligence on the proposed public offering and issue a report on its findings. The debt securities to be issued need to be rated by a CRA accredited with the SECC. Other appointments to be made by the issuer for a public offering of debt securities include a bondholders representative and a securities registrar and transfer and paying agent. The service providers need to be either accredited or registered with the SECC. For details on these functions, please see Chapter III.M.

The issuer also needs to appoint a cash settlement agent, typically a commercial bank, which needs to certify the opening of a separate bank account for the deposit of the issuance proceeds from the public offering.

The Prakas on the Public Offering of Debt Securities also imposes eligibility criteria for an issuer to be able to pursue a public offering and prescribes the individual steps for the issuance of corporate debt securities, which are detailed below. The SECC will further define the format and contents of the application form and disclosure document.

Step 1—Request for Confirmation of Listing Eligibility from the Cambodia Securities Exchange

The issuer-possibly with the help of the securities firm or underwriter servicing the issuer-will need to obtain a confirmation of listing eligibility from the CSX. This confirmation is required as documentation for the actual application to the SECC for the issuance of corporate bonds. Article 36 of the Prakas on Public Offering of Debt Securities stipulates that the issuer needs to comply with all relevant regulations of the permitted securities market on which the debt securities will be listed and traded eventually. The CSX is the only permitted securities market at this point in time.

The listing requirements set by the CSX, and details of its review process, are explained in Chapter III.H.

Step 2-Issuance Application to the Securities and Exchange Commission

The issuer (also termed "applicant" in the regulations) will need to submit an application to the SECC in a form to be prescribed by the SECC. The application needs to be in writing and consist of a number of components that are further detailed below. The issuer may secure the help of the underwriter or securities firm for the compilation of the application and its constituent parts. In any case, the issuer is responsible for the content of the application and the disclosure document, while any service providers, including the underwriter or securities firm (also termed "expert" in the regulations), will be responsible for statements attributed to and information provided by them.

The following documents will need to be submitted together with the application form and the disclosure document:

i. a certified copy of the certificate of incorporation;

ii. a certified copy of the articles of association;

iii. the board of directors' resolution on the public offering of debt securities;

iv. a power of attorney that transfers the right to the director or chief executive officer of the issuer to act on behalf of the company, signed by chairman of the board of directors and all directors;

v. a letter from a commercial bank, acting as cash settlement agent, certifying the opening of a separate account for the proceeds of the public offering of debt securities; 
vi. a report issued by an accounting firm accredited by the SECC that provides audit services, in case financial statements specified in point 3 of Article 6 have not previously been audited by an audit firm accredited by the SECC;

vii. a due diligence report issued by an underwriter licensed by the SECC;

viii. a due diligence report issued by a law firm accredited by the SECC;

ix. a credit rating report issued by a CRA accredited by the SECC;

x. loan agreements (if any);

xi. material agreements (if any);

xii. a certified copy of an underwriting contract or plan for entering into an underwriting contract with the underwriter;

xiii. a certified copy of an agreement with a CRA;

xiv. a certified copy of an agreement with a bondholders representative;

xv. a certified copy of agreements with a securities registrar and transfer and paying agent; and

xvi. the value-added tax certificate, which shall have a tax identification number and documents confirming tax and duty compliance.

In the event that the issuer wishes to issue secured or guaranteed bonds, additional documents will have to be submitted to the SECC; these documents are mentioned in Article 10 of the Prakas on the Public Offering of Debt Securities.

Articles 12-22 of the Prakas on the Public Offering of Debt Securities stipulate the content requirements of the disclosure document itself, which are in line with international standards. Article 12 specifies the minimum content as follows:

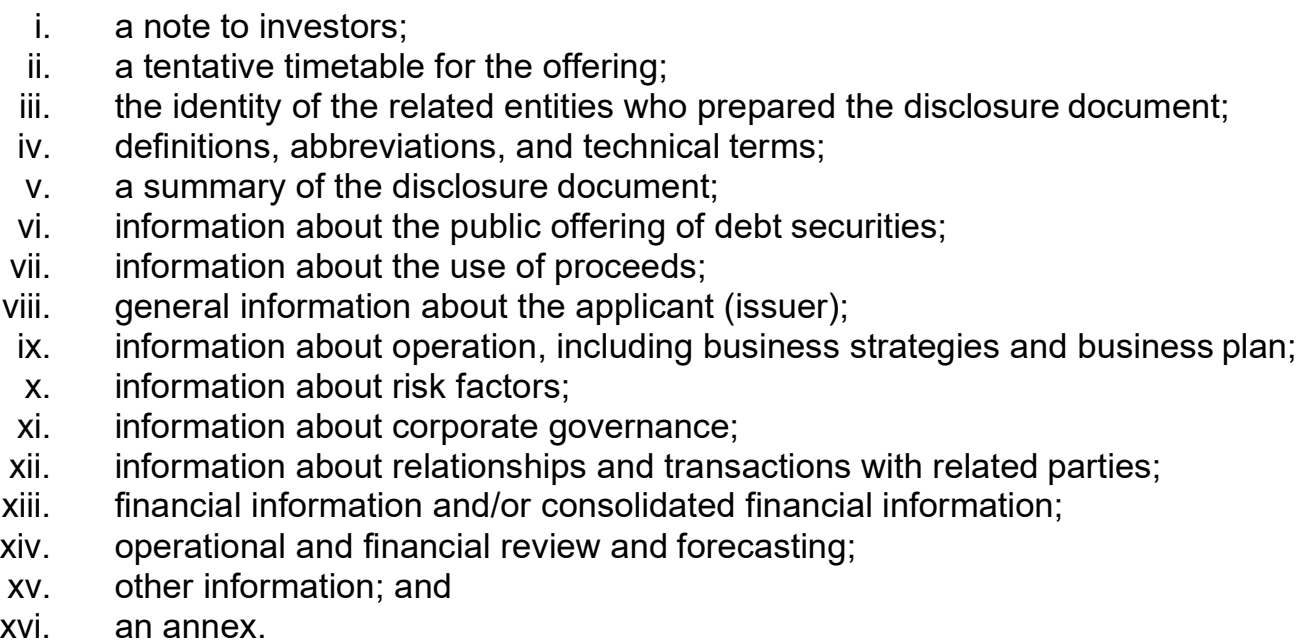

The disclosure document shall also contain the following statement: "All information in the disclosure document is under the responsibility of the issuer and the entities related to the preparation of this disclosure document."

Significantly, the disclosure document must carry the signatures of the chairman of the board of directors of the issuer a well as its directors, chief executive officer, and chief financial officer.

In the annex of the disclosure document, the issuer is expected to include the following:

i. terms and conditions of the debt securities,

ii. code of conduct for directors and senior officers,

iii. asset valuation report (if any), 
iv. auditor's report or accountant's report issued by the SECC-accredited firm providing audit services to the issuer,

v. auditor's report previously issued by a firm providing audit services if it is not accredited by the SECC (if so applicable),

vi. interim financial statement reviewed by an independent auditor (if any),

vii. summary credit rating report issued by a CRA that is accredited by the SECC,

viii. declaration by the applicant (issuer) certifying the accuracy and compliance with relevant laws and regulations of the documents and information submitted to the SECC,

ix. $\quad$ summary credit rating report on the guarantor issued by a CRA accredited by the SECC in case of a guaranteed bond, and

$\mathrm{x}$. experts' consent letters (if any).

Detailing the required information about the public offering of debt securities, Article 14 of the Prakas on the Public Offering of Debt Securities specifies the inclusion of

i. a description of the debt securities by stating the rights and requirements attached to the debt securities being issued;

ii. the terms and conditions of the debt securities;

iii. the price and coupon rate of the debt securities being offered;

iv. the method of price determination of the debt securities;

v. the allotment plan of the debt securities;

vi. all expenses related to the public offering of debt securities;

vii. the appointment, powers, and obligations of the bondholders representative;

viii. conditions for the removal of the bondholders representative;

ix. details on the debt securities holders' meeting;

$\mathrm{x}$. the procedure, date, and place for the settlement of coupon and principal payments;

xi. a description of potential events of default;

xii. material information related to the underwriting contract or the plan forentering into an underwriting contract with the underwriter;

xiii. the credit rating; and

xiv. other information that may be required by the Director General of the SECC.

In the event of secured or guaranteed bonds, the following additional information on the issuer needs to be included:

i. history and development,

ii. strategy and business plan,

iii. business description,

iv. industry overview,

v. group structure,

vi. information related to the issuer's noncurrent assets, and

vii. information about the issuer's tax obligation.

Some of the articles further detail the information required on the use of proceeds, the risk factors the issuer foresees, and the relationships or transactions with related parties. Article 18 prescribes the information necessary on corporate governance exercised by the issuer, namely:

i. information about shareholders;

ii. information about directors, senior officers, and the company secretary and corporate disclosure officer;

iii. information about the board of directors and any board committees;

iv. information about the involvement of directors and senior officers incertain legal proceedings; 
v. information about remuneration or compensation of directors and senior officers;

vi. information about related parties of the applicant (issuer); and

vii. information about other corporate governance conditions that are prescribed in the enacted laws, Anukret, and regulations.

The application to the SECC will need to be accompanied by payment of a fee for the review and registration of the disclosure document by the SECC (please see Chapter VI.A for details). The fee is not refundable even if the application is not successful.

\section{Step 3-Approval-in-Principle from the Securities and Exchange Commission}

The SECC will review the application and supporting documents and may ask, in writing, for additional information or the replacement of information in the disclosure document and supporting documents, as the case may be. In such a case, the issuer (and its service providers) has 15 days from the day the request has been issued to respond to the SECC's request, or any other time period that the SECC may specify, after which the application would either become void or the validity extended if there is a reasonable explanation from the applicant about the delay.

The SECC will inform the issuer in writing of its approval or rejection of the issuance application within 30 days from the receipt of complete documentation.

In case of rejection, the SECC will provide the applicable reasons for which the application was rejected, which may include incomplete, false, or misleading statements; the status of the issuer; or qualifications of a party acting for the issuing company. Article 27 of the Prakas on the Public Offering of Debt Securities contains a full list of possible reasons for rejection.

\section{Step 4-Finalization of Offer Terms and Pricing, Approval from the Securities and} Exchange Commission, and Registration of the Disclosure Document

Following the in-principle approval from the SECC, the issuer may finalize the terms of the public offering, including the pricing for the debt securities. The proposed pricing needs to be confirmed by the CSX as the permitted securities market on which the debt securities are to be listed and traded.

Once the SECC has issued its in-principle approval of the disclosure document, the issuer is able to advertise (see also next step) and to conduct road shows or similar activities, provided it has submitted the necessary details and obtained prior written approval from the Director General of the SECC for these activities.

Upon submission of the final terms of the public offering, the SECC will approve the issuance and then register the disclosure document.

\section{Step 5-Subscription of Debt Securities}

Once the SECC has approved the issuance of debt securities and registered the disclosure document, the issuer may proceed with the public offering within the validity of the disclosure document. In the event that the subscription of the debt securities fails, the registered disclosure document may be cancelled.

The subscription shall be conducted through a securities firm or firms licensed by the SECC. The issuer will need to ensure that the disclosure document will be available for public inspection at its offices, the securities firm, and the CSX within 5 days of obtaining approval from the SECC. 
The securities firm(s) will deposit any subscription moneys received into the dedicated account with the cash settlement agent, and subscriber information will be kept by the securities registrar appointed by the issuer.

The issuer is required to publicly announce the offer through the media and other publication instruments recognized by the SECC at least 5 days before the subscription will take place.

According to Article 38 of the Prakas on the Public Offering of Debt Securities, the announcement is required to contain the following information:

i. the name and country, or other entity, of the issuer;

ii. the number and type of the debt securities to be offered;

iii. the places where the public may obtain the disclosure documentand subscription form of the debt securities;

iv. the date of the subscription of the debt securities;

v. a statement to let the public know that the disclosure document has been approved and registered by the SECC;

vi. a statement specifying that subscribers shall consider subscribing based on documents related to the public offering of debt securities; and

vii. a statement to let the public know that the announcement itself is only to inform the public and does not represent an invitation to subscribe.

Prior to the SECC's approval of the public offering and such announcement, the issuer may already contact potential investors, directly or via securities firms, if an approval for this action was obtained from the SECC and the issuer submitted a list of targeted investors and other relevant documents.

The subscription form and the disclosure document need to be available in printed form; in addition, the issuer is able to distribute the subscription form and disclosure document in electronic form if the contents of the physical and electronic versions are the same.

In case the public offering is not fully subscribed, the underwriter is required to subscribe to the outstanding amount and pay the requisite amount into a separate account with the cash settlement agent within 30 days from the closing date of the subscription.

The issuer, securities registrar, or securities firm(s) shall distribute the debt securities to successful subscribers within 15 working days from the closing date of the subscription of the debt securities.

\section{Step 6-Listing of Debt Securities}

The approval from the SECC and the registration of the disclosure document is the prerequisite for the listing of debt securities on the CSX. At the same time, the listing of debt securities is an integral part of the issuance process for public offerings prescribed by the SECC.

Article 36 of the Prakas on the Public Offering of Debt Securities prescribes that the issuer shall comply with the required process at the permitted securities market. The one market approved by the SECC is on the CSX.

For the detailed listing regulatory process, please see Chapter III.H. 


\section{Issuance Process for a Domestic Financial Institution}

In principle, the regulatory process for debt securities issuance by a domestic financial institution also follows the prescriptions by the SECC, as explained in section 4.

At the same time, banks and financial institutions supervised by the NBC are required to seek a no-objection letter from the central bank for the issuance and subsequent listing of debt securities on the CSX. According to the (Draft) Prakas on Listing Criteria of Banking and Financial Institutions on Cambodia Securities Exchange,to be published by the NBC, additional criteria apply, such as an institution's net worth and the assessment grade given by the NBC.

\section{Regulatory Process for Private Placements}

A general description of private placements exists in the Law on the Issuance and Trading of Non-Government Securities, 2007 and its related Anukret. At the same time, the Prakas on the Public Offering of Debt Securities states in its Article 5 that an issuer who proposes to make a private placement of debt securities shall file the related documents with the SECC, without making further prescriptions.

In the context of the regulatory framework for the corporate bond market, the SECC is expected to further elaborate on provisions for a private placement of debt securities.

Please also see Chapter III.E for the definition of a private placement in Cambodia.

\section{Obligations after Approval and after Subscription}

The Prakas on Public Offering of Debt Securities prescribes the reporting obligations of the issuer or underwriter following the completion of the debt securities subscription. The Prakas also makes a brief reference to the obligations in the case of a private placement.

\section{a. Public Offering}

Pursuant to Articles 29 and 35 of the Prakas on Public Offering of Debt Securities, the issuer shall submit a report of the subscription result to the SECC without delay once the subscription for a public offering is completed. The report must follow the form determined by the Director General of the SECC and include a letter from the cash settlement agent on the amount contained in the dedicated account for the issuance proceeds.

Under Article 20, the issuer must also report details if any of the debt securities were unsubscribed and the underwriter subscribed to the remaining amount.

\section{b. Private Placement}

When the debt securities offer via private placement is completed, the issuer is required to report the result of the private placement to the SECC without delay.

\section{Regulatory Process for Foreign-Currency-Denominated Nongovernment Debt Instruments}

The Government of Cambodia has decided to allow, for a 3-year period from 2018 to 2020 , the issuance of corporate debt securities in the Cambodian market to be denominated in either Cambodian riels or US dollars. At the same time, the 
government encourages issuance in Cambodian riel, which may also attract other incentives to be introduced in the near-term.

\section{G. Continuous Disclosure Requirements in the Cambodian Market}

\section{Securities and Exchange Commission of Cambodia}

According to Article 8 of the Anukret on the Conduct and Organization of the Securities and Exchange Commission of Cambodia, the SECC Department of Securities Issuance Supervision is charged with defining and regulating issuance and disclosure documentation for the offer of securities. Among the department's roles is the ongoing review of financial reports and business reports of public issuing firms. This function was expected to be detailed through Prakas on the continuous reporting obligations of issuers of debt securities.

\section{a. Prakas on Continuous Disclosure}

The actual disclosure requirements have been further defined by the SECC in the Prakas on Corporate Disclosure (No. 002/2012 SECC/Pr.K.), which was promulgated in 2012.

\section{b. Debt Securities Issued via a Public Offering}

The Prakas on Public Offering of Debt Securities references the need for issuers of debt securities to comply with the Prakas on Corporate Disclosure and details specific material events that are to be reported to the SECC under the issuers' continuous disclosure obligations:

i. a board of director's resolution on bondholders' meeting arrangements, indicating the place, time, agenda, and conditions for participation and participants;

ii. a bondholders' meeting resolution after the bondholders' meeting;

iii. any change in the articles of association of the issuer;

iv. when the issuer is unable to pay interest and/or principal according to the debt payment period under the terms and conditions;

v. when there is an interest payment;

vi. when the issuer is planning to delay the interest payment;

vii. when the issuer repurchases part or all of its debt securities in the secondary market;

viii. report to the SECC, after obtaining a credit rating report, annually or within an appropriate time period determined by the Director General of the SECC on the credit rating as prescribed in point 5 of Article 6 of this Prakas until the principal payment is finished; the Director General of the SECC may grant an exemption for reporting on a credit rating by taking into consideration the necessity of the credit rating information for the investors;

ix. when changing a bondholders representative;

$x$. in case of any amendment to the terms and conditions and/or collateral of debt securities, the issuer shall submit the related documents to the SECC within 10 working days; such amendment shall be made through the bondholders' meeting by indicating the reason of such amendment and the effect which occurs or may occur to the bondholders for their decision making;

xi. when an account of the issuer at a bank is frozen, or an account is permitted to be released after having been frozen; and

xii. any material information, which can affect the issuer and/or its credit worthiness. 
The change of a bondholders representative (item 9) requires approval from the Director General of the SECC.

\section{Securities Listed on the Cambodia Securities Exchange}

The issuance of securities to be listed on the CSX must be done via a public offering.

For companies or their securities listed on the CSX, the obligation to provide continuous disclosure information to the CSX is defined in Article 16 (Chapter V, Supervision of Listed Securities) of the CSX Listing Rules. Since the CSX is not a selfregulatory organization (SRO), the Listing Rules are promulgated as an annex to the Prakas on the Implementation of Listing Rules issued by the SECC (No. 004/11 SECC/Pr.K.) in May 2011, pursuant to the Law on the Issuance and Trading of NonGovernment Securities, 2007.

Figure 2.2: Information Disclosure Process for Listed Companies in Cambodia

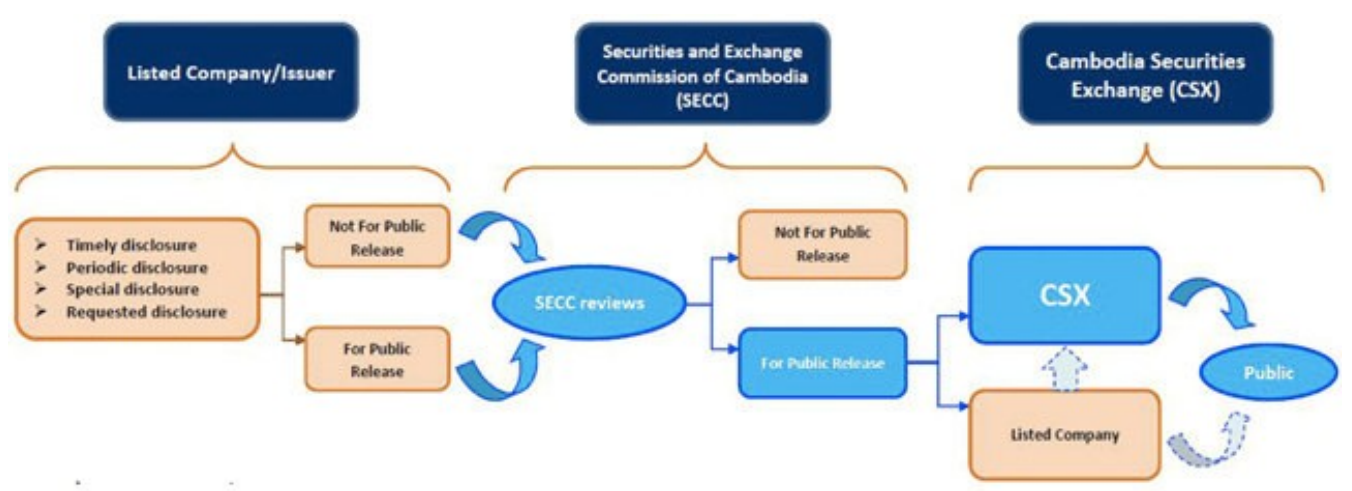

CSX = Cambodia Securities Exchange, SECC = Securities and Exchange Commission of Cambodia . Source: Cambodia Securities Exchange.

The listed company (issuer) of listed securities is required to appoint at least one dedicated disclosure officer who is responsible for providing the disclosure in a timely manner and as specified in the regulations. This includes the following periodic reporting requirements:

- an annual report within 90 days after the end of the financial year,

- a semiannual report within 45 days after the end of a semiannual period, and

- a quarterly report within 45 days after the end of the quarter.

Special disclosure (e.g., in the event of a tender offer or buy-back) as well as specific disclosure information requested by the SECC or the CSX is also required. The disclosure process is illustrated in Figure 2.2. Further details on the continuous disclosure requirements can be found on the CSX website. ${ }^{10}$

\section{H. Self-Regulatory Organizations in the Cambodian Market}

There are presently no SROs in the Cambodian market.

\footnotetext{
${ }^{10}$ See http://csx.com.kh/en/product/disclosure.jsp?MNCD=40302
} 


\section{Approval, Licensing, and Accreditation of Market Participants}

The approval, licensing, and accreditation of market participants in the securities market, including the bond market in Cambodia, comes under the principal purview of the SECC. Approvals and licenses include those for securities market operators, clearance and settlement facility operators, and securities depository operators, as well as securities firms and securities representatives. Accreditations are required for bondholders representatives, CRAs, and audit and law firms.

Cambodia does not practice a universal banking regime and, hence, participants in the securities market, which was put under the supervision of the SECC in legislation and supplementary regulations, must be licensed as a securities firm or securities representative, or accredited according to their service functions.

\section{a. Market Participation as Securities Firms and Securities Representatives}

Chapter 4 of the Anukret on the Implementation of the Law on Issuance and Trading of Non-Government Securities (No. 54 ANKR BK) sets out the detailed provisions for the licensing and conduct of securities firms and securities representatives, pursuant to the Law on the Issuance and Trading of NonGovernment Securities, 2007.

The chapter also specifies exempt securities dealers (e.g., market operator or insolvency administrator) and exempt securities transactions (e.g., government securities issuance), which are not subject to licensing.

The Prakas on Licensing of Securities Firms and Securities Representatives, 2009 further defines the type of business a securities firm may engage in, including securities underwriting and securities dealing or securities broking (see also Chapter III.M.3). A securities firm may also conduct investment advisory services (defined in Article 8 of the Prakas) or other services approved by the SECC. Conducting investment advisory services by a securities firm does not require a separate license, but the SECC requires such securities firms to have individually licensed investment advisor representatives (Article 41).

\section{b. Market Participation as Accredited or Registered Service Provider in the Securities Sector}

Accounting firms, commercial and custodian banks, law firms, securities firms, and securities registrars and transfer and paying agents may also participate in the securities sector as auditors, legal counsel, or bondholders representatives for issuers or investors accordingly (please see Chapter III.M for details). Carrying out any such function requires accreditation with the SECC and is subject to application, supervision, and renewal procedures set by the SECC in individual Prakas for specific functions (see a list of the relevant Prakas in Appendix 2).

The function of the securities registrar and transfer and paying agent requires registration with the SECC.

\section{J. Cambodia Securities Exchange Regulations Related to Listing, Disclosure, and Trading of Securities}

CSX rules are issued in the form of Prakas by the SECC or as an annex to Prakas on specific topics related to CSX operations (including clearing and settlement, and depository roles). 
The SECC, on the request of the CSX, has issued rules for listing; market operation; membership; and clearing, settlement, and depository functions. The respective rules in their current versions are available for download as PDF files in English from the CSX website. ${ }^{11}$

\section{a. Listing Rules}

The CSX Listing Rules are issued in the form of Prakas by the SECC since the CSX is not an SRO. The CSX Listing Rules are amended from time to time upon the recommendation of the CSX to the SECC. At the time of compilation of the Cambodia Bond Market Guide, the latest issue was the Prakas on the Implementation of Listing Rules (No. 006/15 SECC/Pr.K.), dated 10 September 2015.

Issuers must meet the listing requirements prescribed in the CSX Listing Rules. The present listing process is explained in detail on the CSX website. ${ }^{12}$

Going forward, the CSX will have separate listing rules for equities and for debt securities. The listing of debt securities on the CSX is expected to largely follow the same regulatory approval process, with some requirements determined separately, depending on the type of debt securities.

Chapter V (Supervision of Listed Securities) of the CSX Listing Rules refers to the continuous disclosure requirements that are to be further detailed by the SECC. Please see section $G$ in this chapter for details.

\section{b. Market Operation Rules}

In order to describe and govern the trading process and conventions, the SECC has supported the CSX by issuing the Prakas on the Implementation of the Operating Rules of Securities Market, which is applicable for both equity securities and debt securities. The most recent Prakas referring to market operation was the Prakas on the Implementation of the Operating Rules of Securities Liquidity Providing of Cambodia Securities Exchange, issued in August 2016, which is also available for download from the CSX website in English (unofficial translation).

For further details on the trading of (debt) securities, please refer to Chapter IV.

\section{c. Membership Rules}

The CSX Membership Rules were issued as an annex to the SECC's Prakas on the Implementation of the Membership Rules (No. 003/11 SECC Pr.K.) and may be amended from time to time through the issuance of further Prakas. The CSX Membership Rules define and regulate the conduct of members and participants.

As defined in the Prakas, a member refers to a securities firm licensed by the SECC that is a member of the securities market operator, securities clearing and settlement facility operator, and securities depository operator, and which is allowed to use the trading system, securities clearing and settlement system, and securities depository system of the CSX.

\footnotetext{
${ }^{11}$ See http://csx.com.kh/laws/rules/listPosts.do?MNCD=2050

12 See http://csx.com.kh/en/product/listing.jsp?MNCD=40301
} 
In turn, a participant includes cash settlement agents, securities registrars, and securities transfer agents that are authorized to partly use the CSX's market facilities and services, commensurate with their function.

At the end of August 2017, the CSX had 10 members active as securities underwriters, securities dealers, or securities brokers. It also had five participants acting as cash settlement agents, securities registrars, and transfer agents. The list of members and participants may be viewed on the CSX website. ${ }^{13}$

\section{K. Market Entry Requirements (Nonresidents)}

The present legislation and regulations do not specifically prevent or permit foreign investors from participating in the market. In fact, several regulations specifically mention the inclusion of nonresidents or the equal application of said regulations to both resident and nonresident investors. Nonresidents can participate in the IPO of a stock already listed on the CSX.

All investors, domestic and foreign, need to obtain an investor ID prior to investing in the Cambodian securities market. The SECC issues a notice to the market when the contents of the form or the application or approval procedures change. These notices are also viewable on the CSX website under the News and Publication tab.

\section{Nonresident Issuers}

Nonresident (foreign) issuers are not able to issue securities in the Cambodian market at this point in time.

\section{Foreign Investors}

There are no specific market entry requirements for foreign investors. In fact, nonresident investors enjoy the same tax incentives-a $50 \%$ concessionary rebate on the withholding tax rate-as domestic investors.

All investors into the Cambodian securities market must obtain an investor ID prior to buying securities. The only distinction between domestic and foreign investors is an indicator in the actual ID (either "D" or "F" for domestic or foreign, respectively).

Investors may apply directly to the SECC or through their broker. Institutional investors need to fill out Application Form B (Application Form A is for individual investors) and attach their company license, company registration certificate (or equivalent), passport details, and photos of the responsible officers, as well as a power of attorney in their favor.

The necessary steps on how to become an investor in the Cambodian securities market are well explained in the Investor Guide downloadable from the CSX website. ${ }^{14}$ Application Form B is also available for download from the CSX website. ${ }^{15}$

\section{Market Exit Requirements (Nonresidents)}

\footnotetext{
${ }^{13}$ See http://csx.com.kh/en/member/members.jsp?MNCD=10511

${ }^{14}$ See http://csx.com.kh/news/brochure/viewPost.do?MNCD=7040\&postld=86

${ }^{15}$ See http://csx.com.kh/news/notice/viewPost.do?MNCD=8020\&postld=242\#.WBw4BktSgpE
} 


\section{Nonresident Issuers}

Since nonresident (foreign) issuers are not able to issue securities in the Cambodian market at this point in time, exit requirements are not applicable.

\section{Foreign Investors}

There are no specific market exit requirements for foreign investors.

There are no restrictions on foreign investors repatriating funds from divestment or redemption of KHR-denominated assets, USD-denominated assets, or interest and other benefits arising from such investments. Proceeds dominated in Cambodian riels must be converted into a foreign currency with a domestic financial institution before being remitted abroad.

\section{Regulations and Limitations Relevant for Nonresidents}

In principle, there are no limitations for nonresidents-other than issuers of securities - on their activities in the Cambodian market, particularly those related to investment in securities, although certain practices must be observed. A number of noteworthy considerations are mentioned here for reference.

\section{Currency Exchange Controls}

The Cambodian riel is nonconvertible and nonnegotiable outside Cambodia. Foreign currency remittances must be converted with a domestic financial institution into Cambodian riel proceeds prior to the purchase of securities.

\section{Bank Accounts in Domestic or Foreign Currency}

There are principally no restrictions for nonresidents on maintaining bank accounts in Cambodia. Nonresidents may open accounts in Cambodian riels as well as in US dollars with a commercial bank if they can provide the required documents.

\section{Borrowing and Lending}

The borrowing and lending of cash by nonresidents is possible in both Cambodian riels and US dollars.

\section{N. Regulations on Credit Rating Agencies}

As part of a comprehensive set of measures to develop the corporate bond market, the SECC introduced the Prakas on Accreditation of Credit Rating Agency in August 2017. This regulation addresses the eligibility criteria and requirements for CRAs to operate in Cambodia. The accreditation has no expiry date.

Prescriptions include the minimum content of the credit rating report, the need to have experienced management and staff, operating procedures, a code of conduct, a mechanism to avoid conflicts of interest, and minimum capital requirements. CRAs will need to submit an application with relevant documents to demonstrate that the requirements have been met. The SECC will decide on the application within 45 days from the receipt of complete documents and notify the applicant in writing.

A CRA will need to have a rating committee, consisting of at least three persons-one director and two analysts—and must ensure the committee's independence. The 
operational prescriptions also contain the restrictions for when a CRA will be unable to act as rating agency for a company. A CRA will have to submit an annual report to the SECC, together with the latest audited statements, within 90 days after the end of a financial year.

The SECC will also issue a list of international CRAs that are eligible to carry out rating activities for credit-rated entities (issuers) in the Cambodian capital market.

The Prakas may be further detailed by the SECC through the issuance of guidelines.

The actual credit rating requirements for debt securities in the Cambodian market will be further defined in time. Once defined, the requirements for and the application of such credit ratings in the issuance process of debt securities will be described in detail in Chapter III.O. 


\section{Characteristics of the Cambodian Bond Market}

The Cambodian securities market has made significant progress since the introduction of the Law on Issuance and Trading of Non-Government Securities and the Law on Government Securities, 2007 and the establishment of the SECC in 2008. Under the guidance of the MEF and the SECC, the market is expected to rapidly develop in the coming years. In fact, with the regulatory framework for the corporate bond market published in August 2017 and a sub-decree on the issuance of government securities under development by the MEF, a firmly established bond market is expected within the next 12-18 months.

The purpose of this chapter is to take stock of the existing features of the Cambodian market and to review some of the characteristics of the planned Cambodian bond market.

\section{A. Definition of Securities}

The current fundamental and key legislation does not yet contain a consolidated definition of securities. Securities are mentioned only as a collective term and some examples are given (e.g., the annex of the Law on Issuance and Trading of NonGovernment Securities, 2007). In turn, definitions for individual types of bonds are provided in the Prakas on Public Offering of Debt Securities (No. 009/17 SECC/Pr.K.), particularly for corporate bonds:

Corporate Bond refers to debt securities issued by the public limited company or permitted entity that have been confirmed the obligation to pay interest, principal, and other obligations of the business for the bondholders.

The Prakas also contains definitions of plain bond, guaranteed bond, and secured bond.

\section{B. Types of Bonds and Notes}

At present, bonds and notes are not yet being issued in the Cambodian market by either the government or the corporate sector.

As one of its medium-term goals under the FSDS (updated for the 2016-2025 period), the Government of Cambodia is pursuing the development of the MEF's capacity to issue government securities (see also Chapter I.B). At the same time, the regulatory framework for corporate bonds (nongovernment debt securities) put in place by the SECC in August 2017 is expected to lead to the issuance, listing, and trading of debt securities in the next 12-18 months. 


\section{Money Market Instruments}

To kick off its interbank money market project, the NBC issued the Prakas on Issuance of Tradable Securities by the NBC (No. B-5-010-183) on 15 October 2010. After a 3year preparation timeframe, the NBC commenced issuance of negotiable certificates of deposit (NCDs) on 9 September 2013.16

The issuance of NCDs is intended to provide banks with a previously unavailable means to manage excess liquidity.

\section{Issued by the National Bank of Cambodia}

\section{a. Negotiable Certificates of Deposit}

An NCD is a short-term, interest-bearing debt instrument issued by the NBC. The minimum denomination for investment is KHR200 million or USD50,000. The maturities of KHR-denominated NCDs range from 2 weeks to 1 year, and the maturities of the USD-denominated NCDs range from 2 weeks to 6 months. The interest rate of an NCD is determined by the NBC daily according to market conditions.

An NCD can be traded in the interbank market or used as collateral for the credit facility provided to banks by the NBC, used for credit purposes among banks, or repurchased by the NBC at a discount before maturity.

\section{Methods of Issuing Debt Securities (Primary Market)}

The regulatory framework for the issuance of nongovernment securities allows for both a public offering and private placement. Please see Chapter II.F for descriptions of the regulatory process for each issuance method.

At the same time, the Government of Cambodia, through the MEF and the GDNT, has been pursuing a longer-term plan to issue government securities. In fact, the MEF is presently drafting an Anukret to implement the Law on Government Securities, 2007 at the appropriate time.

The NBC already issues NCDs directly to the banks that participate in the interbank money market (see section $\mathrm{C}$ ).

\section{Expected Issuance of Government Securities}

Budget management is the responsibility of the GDNT, which started operation in January 1991. The GDNT is also responsible for the management of public debt. To address the expected cessation of concessionary funding, the GDNT is targeting the issuance of government securities in line with the FSDS (see also Chapter I.B). ${ }^{17}$ The methods described below are expected to be utilized when the issuance of government securities commences.

\section{a. Issuance via Auction System}

\footnotetext{
${ }^{16}$ For details on the interbank market project, please refer to the NBC website at http://www.nbc.org.kh/english/monetary_policy/ncds_overview.php

${ }^{17}$ Cambodia's financial year is the same as the calendar year (1 January to 31 December).
} 
Following a number of consultations with $A D B$ and $A B M F$, the MEF has signalled a preference for exploring the use of an auction system to issue government bonds.

The type of auction, its pricing mechanism(s), and the number and qualification of participants are being researched to cater to the specific financing needs of the government.

In the context of using an auction system, the benefits of eventually establishing a primary dealer concept have been acknowledged by the MEF.

\section{b. Direct Issuance}

At the same time, the MEF is considering the possibility of direct issuance of government securities, in particular Treasury bonds, through the NBC to the bank and financial institution participants in the central bank clearing system.

Additionally, direct issuance to interested and eligible investors in the Cambodian market may also be considered.

\section{Direct Issuance by the National Bank of Cambodia}

NCDs are issued by the NBC directly to participating financial institutions on a demand basis. Banks with the need to manage excess liquidity in both Cambodian riels and US dollars approach the NBC during stipulated operating hours to place money with the NBC in return for the issuance of NCDs in suitable denominations and maturities.

\section{Issuance of Corporate Debt Securities}

Laws and regulations favor the issuance of nongovernment (corporate) debt securities in the Cambodian market via public offerings and further link a public offering to the listing of debt securities on the CSX. At the same time, a definition of private placement already existed in law and supplementary regulations, and was further distinguished from a public offering in the context of the introduction of the regulatory framework for corporate bonds by the SECC.

\section{a. Public Offering}

The Law on the Issuance and Trading of Non-Government Securities, 2009, as well as its related Anukret and subsequent Prakas, focus on the issuance of debt securities via a public offering. The listing of debt securities on the CSX has a public offering as one prerequisite.

A public offering is the selling of securities to the broad market rather than to a select or limited group of investors. The original provisions for public offerings are contained in Chapter 2 (Proposed Public Offering and Issuance of Securities) of the Anukret on the Implementation of the Law on Issuance and Trading of Non-Government Securities (No. 54 ANKR BK) issued in April 2009. ${ }^{18}$ Article 6 of this chapter allows for exempt offers such as issuances by the Government of Cambodia and those specifically approved by the SECC. In August 2017, the SECC published detailed prescriptions in the Prakas on Public Offering of Debt Securities providing for the issuance of corporate debt securities as plain bonds but also allowing for the issuance of guaranteed and secured bonds.

\footnotetext{
${ }^{18}$ Available as a PDF file from the SECC website at http://www.secc.gov.kh/english/m22.php?pn=3
} 
To issue securities through a public offering, the issuing company (a public limited company or other permitted entity) must obtain approval from the SECC for the issuance and from the CSX for the subsequent listing and adequate issuance pricing. Other articles in the Anukret and, particularly, the aforementioned Prakas stipulate the need for an application process and content requirements for the disclosure document and any necessary supplementary documentation and additional information. The disclosure document will be registered by the SECC upon issuance approval.

\section{b. Private Placement}

The Law on Issuance and Trading of Non-Government Securities, 2007 contains a basic definition of a private placement.

Subsequently, the Prakas on Public Offering of Debt Securities, promulgated in August 2017, further distinguished a private placement from a public offering as an offer to no more than 30 persons within a 1-year period and where there is no advertisement to the public, no public solicitation of the offer, and no advice on investment in such securities.

Any issuance contrasting with the above prescriptions is considered a public offer and will have to comply with the requirements set for such an offering.

In the context of the introduction of the regulatory framework for the corporate bond market, the SECC is expected to further elaborate on the provisions for a private placement of debt securities.

\section{E. Governing Law and Jurisdiction (Securities Issuance)}

The governing law and jurisdiction for a bond or note issuance may be of significance since potential issuers can issue under the laws or jurisdiction of a country or market other than the place of issuance. The choice of governing law or contractual preferences of stakeholders can affect the accessibility to a specific investor universe that may otherwise not be accessible if a bond or note was issued under the laws of the place of issuance.

In Cambodia, the governing law and the jurisdiction of agreements by contracting parties are required to be Cambodian law and the Kingdom of Cambodia, respectively. At the same time, while a request for the use of another law or jurisdiction has not yet been received, the SECC may offer some flexibility such as consideration on a caseby-case basis for issuers to use the laws or jurisdictions of countries for which it has entered into a memorandum of understanding with the respective securities market regulatory authorities. It is likely that taxation considerations will also play a role in the SECC review and decision.

\section{F. Language of Documentation and Disclosure Items}

Presently, all contracts, applications for securities issuance and listing, licensing or accreditation approvals, and securities issuance documentation and disclosure items, as well as correspondence with regulatory authorities and market institutions (if so required), must be in Khmer, which is the official language of Cambodia.

During the application for the issuance of securities, the SECC requires all contracts in relation to such issuance to be submitted. According to provisions in the Anukret on the Implementation of the Law on Issuance and Trading of Non-Government 
Securities, 2007 (No. 54 ANKR BK), contracts that are not originally written in Khmer shall be attached and translated into Khmer by persons recognized by the SECC.

At the same time, the disclosure document for the issuance of securities may also be in English. It may be produced first in English as long as the final version of the disclosure document will be available in Khmer at the time the offer of securities to the public commences.

In this context, the SECC also typically publishes relevant Prakas for the securities market in both Khmer and English on its website. The CSX website also offers English versions of the Prakas for the securities market, particularly those that contain listing and disclosure, market, and post-trade operation rules.

\section{G. Registration of Debt Securities}

The registration of securities in the Cambodian market is for the purpose of evidence of ownership, not for disclosure purposes, as the case may be in other ASEAN+3 markets. Please see section $L$ in this chapter for details on transfer of interests or ownership.

As a matter of distinction, the term "registration" is also used in the Cambodian market, particularly for the acceptance of the disclosure document by the SECC, upon issuance approval, in the context of a debt securities issuance application.

\section{H. Listing of Securities}

A listing of securities in Cambodia is possible on the CSX. The systems and practices of the CSX have been adapted from infrastructure provided by Korea Exchange, its joint venture partner, and are principally able to handle debt securities as well. The CSX systems are expected to be in place by the end of 2017 and the Prakas on the Implementation of Debt Securities Listing shall be promulgated upon the SECC's review and approval, which is expected by early 2018 .

Recent legislation and regulations, including those on tax incentives for the securities sector (see Chapter VI), refer to the listing of both equity and debt securities. The Prakas on Public Offering of Debt Securities issued in August 2017 specifically links the listing of debt securities to a public offering of said securities. Article 36 of the Prakas stipulates the need for the issuer to comply with the procedures set by the permitted securities market for the listing and trading of the debt securities. The CSX is presently the only permitted securities market.

\section{Actual Listing Process}

In addition to equity and debt securities issued via a public offering, other debt securities may be listed on the CSX, including in the form of a profile listing (no trading) provided that the issuer and debt securities fulfill the eligibility criteria set by the CSX as the listing authority and comply with its Listing and Disclosure Rules.

The actual listing process consists of two major steps: (i) determination of thelisting eligibility of the issuer and securities to be listed, and (ii) listing approval. The listing eligibility part encompasses the submission of the listing application and supporting documents and the CSX's check on disclosure and the supporting information; the listing approval is a formality once the issuer has completed all necessary steps. 
Step 1-Listing Application to the Cambodia Securities Exchange; Listing Eligibility Review

The CSX requires a Listing Application Form in the form of two hard copies that need to be submitted in Khmer. The attachments to the listing application may be in either Khmer or English, while the CSX will accept disclosure and supplementary documents if they are only available in English.

The disclosure requirements imposed by the CSX are based on the Prakas on Corporate Disclosure (No. 002/12 SECC/Pr.K.) issued by the SECC in April 2012. The Prakas is available in English from the SECC website. ${ }^{19}$ The CSX permits the incorporation by reference of disclosure items at the time of the listing application and for continuous disclosure thereafter.

The CSX will conduct its Listing Eligibility Review after receiving the completed Listing Application Form with all necessary supplementary documents. Once the CSX is satisfied that the issuer and the debt securities comply with its listing requirements, it will issue a Confirmation of Listing Eligibility to the issuer as a physical letter. The CSX commits to respond to the listing application from the issuer within 2 weeks from the receipt of complete information.

To obtain approval for the issuance of debt securities via a public offering from the SECC, the Confirmation of Listing Eligibility is a mandatory input document.

\section{Step 2-Listing Approval from the Cambodia Securities Exchange}

Once the issuer has obtained the issuance approval from the SECC (for public offering) or has completed the necessary steps prior to a profile listing, the issuer will send a request to the CSX for the actual listing.

The issuer will need to sign a Securities Listing Agreement with the CSX, in a format approved by the SECC, prior to listing; the agreement will take effect on the effective listing date.

The CSX will check on the status of the issuer-based on its due diligence at the time of the Listing Eligibility Review_and respond within 5 days with its listing approval and the effective listing date information. The listing approval will be in writing in Khmer.

\section{Profile Listing on the Cambodia Securities Exchange}

The CSX allows a listing for profiling on its market, which represents a listing where trading on the exchange is not expected. The profile listing process follows the one for the standard listing-cum-trading applications and carries the same requirements for eligibility and compliance with the CSX Listing Rules and Disclosure Rules. A profile listing also requires the same approval from the SECC as other listings.

At the same time, the CSX's functionality allows participants to record offer prices for debt securities that are profile listed, as a price-finding mechanism for trading members and market participants, since the CSX presently is the only official pricing platform for the Cambodian securities market. Please see Chapter IV.B for details.

\footnotetext{
${ }^{19}$ For details, see http://www.secc.gov.kh/english/m23.php?pn=3
} 


\section{Methods of Trading Securities (Secondary Market)}

At present, the only method of trading of securities approved by the SECC pursuant to the Law on the Issuance and Trading of Non-Government Securities, 2007 is on the CSX as the only permitted securities market. The trading of securities has occurred on the trading platform of the CSX since 2011. It is expected that the CSX will be able to list and trade debt securities, following the introduction of the regulatory framework for corporate debt securities in August 2017, since the CSX' platform partner is Korea Exchange, which is known for significant debt securities trading on its markets.

\section{J. Securities Pricing}

In line with the current stage of development of the Cambodian securities market, there is no dedicated securities pricing agency domiciled in Cambodia. However, the securities presently issued in the market are priced daily and competitively in their respective market segment, namely the CSX for listed securities and the NBC for money market instruments.

\section{Pricing of Securities on the Cambodia Securities Exchange}

Trades in securities listed on the CSX are executed based on the auction concept. Orders from buyers and sellers are matched according to the predetermined auction principles, allowing for a representative price-finding mechanism for the securities.

The CSX publishes comprehensive data on daily trading activities on its website. An example of the data published is shown in Figure 3.1.

\section{Pricing of Negotiable Certificates of Deposit by the National Bank of Cambodia}

The NBC determines the price of NCDs to be issued and traded on a daily basis in line with market conditions. Interbank market participants use the NCD prices published by the NBC to guide them in their own assessment and pricing of trades with counterparties.

Figure 3.1: Daily Securities Prices on the Cambodia Securities Exchange Website 


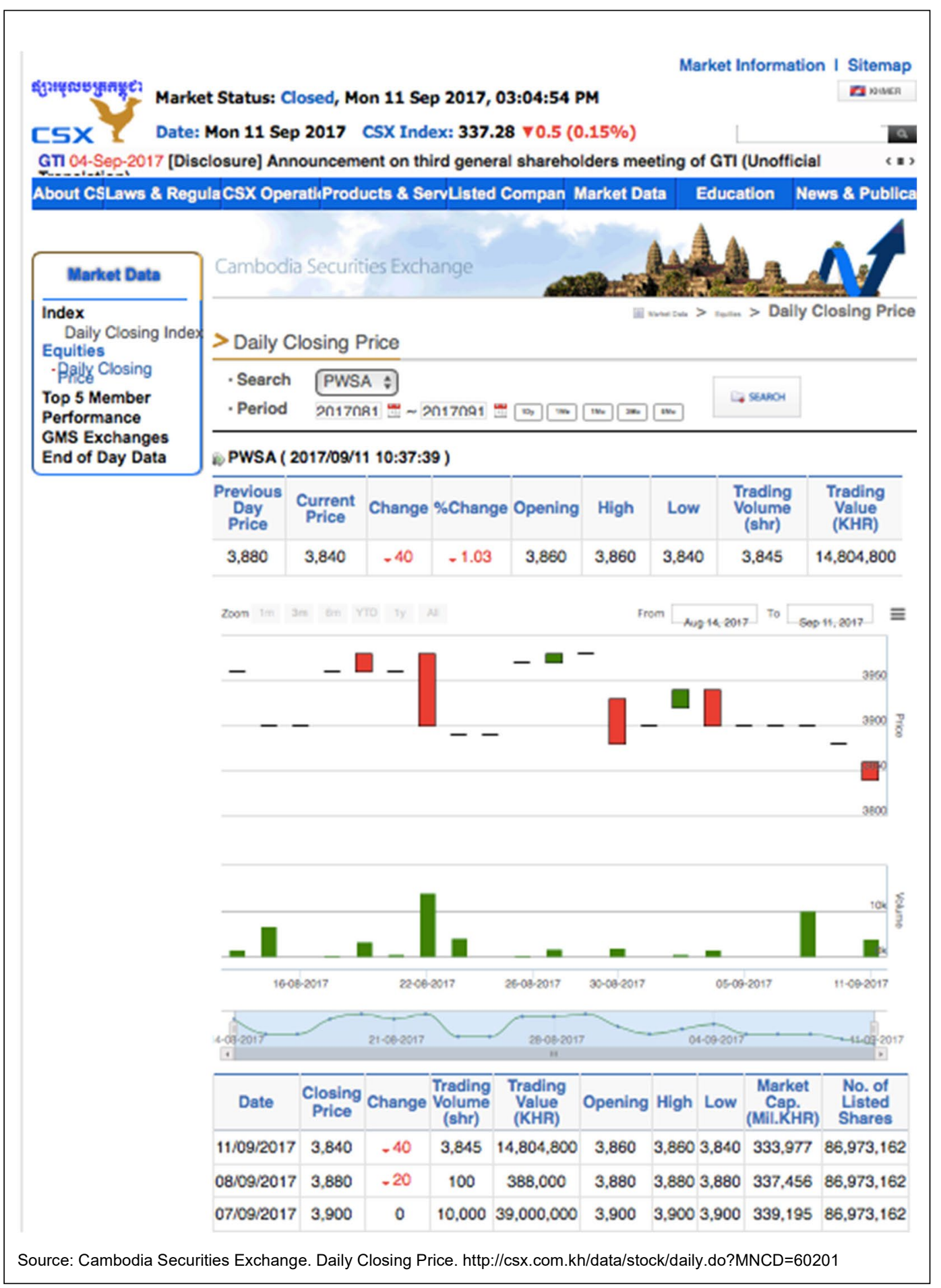

\section{K. Transfers of Interest in Bonds and Notes}

The registration and transfer of ownership of securities, including debt securities, depends on the type of securities and the permitted securities market they are transacted in.

1. Securities Listed on the Cambodia Securities Exchange 
Securities listed and traded on the CSX are registered in the books and records of a licensed securities registrar and transfer agent-as a participant of the exchange (see also Chapter II.J) - for each of the securities. In the CSX Depository, securities are transferred by book-entry; that is, the recording of an applicable debit or credit of the amount of securities in the member and participant account books without the actual movement of physical certificates.

Legal ownership changes when the transfer is recorded in the book of the operator of the securities depository of the CSX.

\section{Securities Issued by the National Bank of Cambodia}

At present, only NCDs are issued by the NBC. NCDs are issued in scripless form and transactions are recorded in a ledger at the NBC. The ownership of individual NCDs by banks is recorded in the books of the NBC. In the event of a transaction in the interbank market, the NBC will effect the transfer of ownership once it receives confirmation of the transaction from both the seller and buyer.

\section{Transfers without Trading}

Applicable regulations are currently not available for the transfer of securities without an underlying trade or transaction, with practical exceptions in line with international standard practice. As a result, the transfer of securities free of payment as the result of a donation, an inheritance, a court order, or a pledge may be processed. The SECC is in the process of preparing a Prakas specifically on this subject.

\section{Market Participants}

The following market participants are either active in the securities market or are envisaged as participants in the eventual corporate bond and government securities market segments.

\section{Issuers}

With the introduction of the regulatory framework for nongovernment (corporate) debt securities in August 2017, potential issuers of corporate bonds could include existing listed and unlisted companies intending to diversify their debt portfolio.

Future potential issuers of government securities could include the NBC, the Debt Management Office of the MEF, other government agencies, and state-owned enterprises.

The NBC already issues NCDs as a money market instrument to its bank and financial institution constituents as part of its open market operations and to help manage minimum reserve requirements. In principle, the NBC could issue short-term government bonds on behalf of the government if this is seen as beneficial.

\section{Investors}

With the government bond market likely commencing operation in 2019 and the imminent commencement of the corporate bond market following the introduction of the necessary regulatory framework, a number of investor types already present in the Cambodian market (described below) are envisaged to participate.

\section{a. Banks}


Banks typically are active participants in the bond market, either on behalf of their customers or for proprietary purposes. In most markets, banks are permitted to hold bonds of a certain quality as part of their minimum reserve requirements, which also makes them keen investors in the bond market. Banks are considered Qualified Investors by the SECC.

Banks may in future also use bonds to obtain short-term liquidity from the NBC through a discount window or similar process, as deemed suitable by the NBC.

\section{b. Non-Bank Financial Institutions}

Typical non-bank financial institutions include finance and leasing companies who may also be active as investors in the bond market to satisfy statutory reserve requirements and/or to invest liquid assets.

\section{c. Insurance Companies}

Given the nature of the insurance business and the need to observe prudential capital requirements, insurance companies are typical investors in the bond market. At present, the absence of debt securities in the Cambodian market is leading to insurance companies investing mainly in fixed-term bank deposits, short-term loans, or short-term real-estate transactions. ${ }^{20}$ Insurance companies are considered Qualified Investors by the SECC.

In Cambodia, the MEF, through the Insurance and Pension Division of the General Department of Financial Industry, issues licenses for general insurance services under the provisions of the new Law on Insurance, promulgated on 4 August 2014, and Anukret No. 132 on Insurance, which was passed in 2001 and remains in force. At the time of the compilation of the Cambodia Bond Market Guide, the domestic insurance market consisted of seven general insurance companies, four life insurers, and one reinsurance company. All licensed insurance companies are members of the Insurance Association of Cambodia. ${ }^{21}$

\section{d. Pension and Provident Funds}

Pension and provident funds are typical bond market investors and, in Cambodia, are able to invest in debt securities issued in Cambodia.

\section{e. Collective Investment Schemes}

Collective investments schemes, typically in the form of mutual funds or unit trusts, and the asset managers that operate these and other asset pools are typical key investors in debt securities. Collective investments schemes are included as Qualified Investors.

Chapter 5 of the Anukret on the Implementation of the Law on Issuance and Trading of Non-Government Securities contains provisions for collective investment schemes (both for companies and under a collective investment contract), related persons, and their licensing.

f. Retail or General Investors

\footnotetext{
${ }^{20}$ As an example, reference is made to the website of the Cambodian National Insurance Company, http://www.caminco.com.kh/profile.html

${ }^{21}$ See http://www.iac.org.kh/index.php/about-us/brief-history
} 
Retail or general investors, referred to typically as public investors under regulations (see also section $\mathrm{N}$ ), may not be an immediate investor type once a bond market is established. However, depending on interest rates and market conditions, government bonds especially may provide a safe alternative to other assets. Other economies in ASEAN+3 have created specific bond types for distribution to retail or general investors, with potentially higher interest rates and smaller denominations to cater to the savings objectives of the broader public.

\section{g. Foreign Institutional Investors}

Foreign institutional investors are principally able to participate in the securities market at large (see also Chapter II.K). Foreign institutional investors have already been observed participating in the IPOs of stocks listed on the CSX.

\section{Parties Involved in Debt Securities Issuance}

A number of intermediaries are already established in the Cambodian securities market and are expected to be able to service nongovernment debt securities (corporate bonds), their issuers, and their investors once the issuance of these debt securities commences. These intermediaries range from securities underwriters, securities dealers, and securities brokers participating on the CSX, to banks, law firms, and accounting and audit firms, all of which require either licensing or accreditation by the SECC.

These entities are intermediaries under the provisions of the Law on the Issuance and Trading of Non-Government Securities, 2007 and as prescribed by the Prakas on Licensing of Securities Firms and Securities Representatives, 2009 and other Prakas specific to market functions.

As a practical guide, the market participants that are by their license or accreditation already positioned to participate in the bond market are being reviewed here.

\section{a. Securities Firms}

The Law on the Issuance and Trading of Non-Government Securities, 2007 specifically mentions securities companies, securities dealers, and securities brokers as participants in the securities market.

The Prakas on Licensing of Securities Firms and Securities Representatives, 2009 further details prescriptions for securities firms, which may conduct the following types of business: securities underwriting, securities dealing, and securities brokerage. These types of business are further defined in Articles 5, 6 , and 7 of the Prakas, respectively. Securities firms licensed for any of the business types listed above may only engage in the specific activities as further described in Articles 9, 10, and 11, respectively. Any natural person who has obtained a license as a securities representative mayundertake the activities as prescribed in Article 12 of the Prakas. ${ }^{22}$

A securities firm may also conduct investment advisory services (defined in Article 8) or other services approved by the SECC. Conducting investment advisory services by a securities firm does not require a separate license but the SECC requires such securities firms to have individually licensed investment advisor representatives (Article 41).

${ }^{22}$ The Prakas is available as a PDF file on the SECC website at http://www.secc.gov.kh/english/m23.php?pn=3 
At the time of compilation of the Cambodia Bond Market Guide, six securities underwriters, one securities dealer, and three securities brokers had been licensed by the SECC. The license refers to securities in totality, with no specific mention of debt securities. All of the licensed institutions are also members of the CSX.

\section{b. Underwriter(s)}

Presently, six securities underwriters are members of the CSX, meaning that these institutions have received a license to conduct underwriting business for securities in Cambodia under the Law on the Issuance and Trading of NonGovernment Securities, 2007. ${ }^{23}$ Such a license does not limit the securities to equities.

The issuer must appoint an underwriter for the offer of securities to the public.

It is envisaged that practicing underwriters, all of which are securities firms (see also section 4.b), may expand their business to include underwriting debt securities once issuance in the Cambodian market commences.

\section{c. Securities Registrars, Securities Transfer Agents, and Paying Agents}

These intermediaries are regulated pursuant to the Prakas on the Registration of Securities Registrar, Securities Transfer Agent, and Paying Agent, 2010, which stipulates the requirements for these service providers and the obligations to carry out the permitted services. ${ }^{24}$

Securities registrars and securities transfer agents are required to record the holdings of the respective securities and the ownership and transfer of ownership of the securities by investors. Paying agents service the issuer by providing services such as the distribution of the dividend or interest income to be paid by the issuer of securities and the withholding and onward remittance of applicable taxes.

At the time of compilation of the Cambodia Bond Market Guide, two securities registrars and transfer agents had registered with the SECC. Both are listed on the CSX website.

\section{d. Bondholders Representative}

The bondholders representative function was introduced by the SECC in August 2017 in the context of the regulatory framework for corporate bonds.

A bondholders representative may be a commercial or custodian bank; a securities firm; or a securities registrar, securities transfer agent, and paying agent. Since these firms are already licensed or registered market participants, a bondholders representative needs to be accredited with the SECC to carry out its functions.

Interested parties will have to apply for a bondholders representative accreditation and have to fulfill certain eligibility criteria specified in the Prakas.

Please see section $Q$ in this chapter for details on the functions and specific responsibilities of a bondholders representative.

\footnotetext{
${ }^{23}$ For a current list, please see http://csx.com.kh/en/member/members.jsp?MNCD=10511

${ }^{24}$ The Prakas is available as a PDF file on the CSX website at http://csX.com.kh/laws/prakas/viewPost.do
} 


\section{e. Custodians}

At present, securities firms hold securities for their client in segregated client accounts under the name of the securities firm with the CSX, which also acts as depository. The SECC recognizes that investors require formal custodian services and is in the process of drafting Prakas on the subject of custodian business practices.

In a mature market, custodians are typically banks or broker-dealers. The Law on the Issuance and Trading of Non-Government Securities, 2007 identifies safekeeping, clearing, and settlement as distinct activities by market participants. Future Prakas and circulars are expected to further describe the permitted market activities under these functions.

f. Law Firms

Law firms are required to be accredited with the SECC for providing services in the securities sector.

\section{g. Audit Firms}

All firms conducting business in the securities sector may only select their service providers from among professional accounting firms and external auditors accredited with the SECC.

Pursuant to the Prakas on Accreditation of Professional Accounting Firm Providing Professional Services in the Securities Sector, 2010, professional firms must obtain accreditation from the SECC to be involved in the issuance of securities or to service issuers or any other securities market participants. Articles 10 and 11 of the Prakas contain specific provisions to avoid potential conflicts of interest by professional firms.

A professional accounting or audit firm that applies for accreditation with the SECC needs to meet a number of requirements, which include a minimum amount of capital, number of staff and clients, and years in operation.

The accreditation is valid for 3 years. To stay accredited, accounting and audit firms have to submit an application for renewal of their respective accreditation to the SECC at least 45 days before the expiry of the existing accreditation.

In addition, these professional firms have to be accredited with their industry body, the Kampuchea Institute of Certified Public Accountants and Auditors. This accreditation is to be proven at the time of application to the SECC.

\section{Public Investor and Qualified Investor Concepts}

The SECC issued the Prakas on Qualified Investors in the Securities Sector (No. 005/2016 SECC/Pr.K.) in August 2016. With the publication of the Prakas, the SECC introduced to the market the Qualified Investor concept, which distinguishes between a number of defined investor types and sets their eligibility and qualifying criteria. Like all Prakas issued by the SECC, its text is available for download as a PDF file-in both Khmer and English-from the SECC website. ${ }^{25}$

\footnotetext{
${ }^{25}$ See http://www.secc.gov.kh/english/m23.php?pn=3\&no=32
} 
At the same time, a definition of "public investors" already existed in previous regulations.

\section{Qualified Investors}

The Prakas on Qualified Investors in the Securities Sector introduced and defined the terms "Qualified Investor," "Institutional Investor," and "High Net-Worth Investor" in the securities market in Cambodia. Qualified Investors may be Institutional Investors or High Net-Worth Investors.

The requirements for Qualified Investors, included in Article 3 of the Prakas, are as follows:

Institutional Investors include

i. the NBC;

ii. securities firms and investment advisors that have obtained licenses from the SECC;

iii. collective investment scheme dealers that have obtained licenses from the SECC;

iv. banking and financial institutions that have obtained licenses from the NBC;

v. insurance companies that have obtained licenses from the MEF;

vi. the National Social Security Fund, National Fund for Veterans, Persons with Disabilities Foundation, and National Social Security Fund for Civil Servants;

vii. international financial institutions that have obtained approval from the Director General of the SECC;

viii. Financial Institutions Development Funds that have obtained approval from the Director General of the SECC; and

ix. other legal entities that have obtained an approval from the Director General of the SECC.

High Net-Worth Investors include

i. legal entities fulfilling one of the following criteria:

a. total shareholders' equity of at least KHR2 billion as per the latest financial statement,

b. annual revenue of at least KHR500 millions in the last 2 years, or

c. at least KHR200 million of investments in the securities sector in Cambodia; and

ii. any individual who aims to register as a Qualified Investor and, together with a spouse (if any), fulfills one of the following criteria:

a. total net assets of at least KHR1 billion,

b. annual income of at least KHR80 million, or

c. investment participation in the securities sector in Cambodia of at least KHR100 million.

Institutional investors must submit official documents and other necessary information stating their eligibility to the securities firms before they can be registered as such.

High Net-Worth Investors are required to complete a form set by the securities firm and approved by the Director General of the SECC, and attach bank statements, investment reports, or similar documents confirming their compliance with the qualifying criteria mentioned above. 
Securities firms are required to verify the information provided by Qualified Investors and submit a list of such Qualified Investors to the SECC on a periodic basis after having ascertained that the qualifications continue to be met.

\section{Public Investors}

In regulations, "public investor" refers to a member of the public in Cambodia, including a natural person or legal entity, who has the financial and legal capacity to invest in nongovernment securities issued through a public offering in Cambodia by a public limited company or permitted entity that is not its associate, subsidiary, or related legal entity.

\section{N. Credit Rating Requirements}

This section reviews the credit rating requirements for nongovernment (corporate) debt securities in the Cambodian market. For details on the accreditation of a CRA to carry out rating activities in Cambodia, please refer to Chapter II.N.

A credit rating is required if the issue is a plain or secured bond. If the issue is a guaranteed bond, a credit rating on the issue is not required, but the guarantor of the bond needs to be rated.

In case no CRA has been accredited by the SECC, the issuer shall submit a report on the level of ratios such as profitability and cash flow ratio, leverage ratio, coverage ratio, and other such applicable ratios, together with a certification of their appropriateness from the underwriter or the experts appointed by the issuer.

\section{O. Market Features for Investor Protection}

\section{Investor Complaints}

Investors who have reason to file a complaint about their treatment are encouraged to make representations to the securities firm at which they maintain an account. If the response is unsatisfactory, investors can involve the CSX for rectification or mediation, as may be necessary. If such efforts fail, the investor can escalate the complaint to the SECC.

\section{Bondholders Representative Function}

The SECC introduced the bondholders representative function in a dedicated Prakas in August 2017, as part of the regulatory framework for the issuance of nongovernment (corporate) debt securities in the Cambodian market. The purpose of the function is to represent the interest of bondholders by monitoring the status of the issuer and the terms and conditions of the debt securities, and in the event of default or bankruptcy of the issuer.

Please see section $Q$ for further details.

\section{Trust Law at Draft Stage}

At present, the Government of Cambodia is drafting a dedicated Trust Law, which may support the market framework of investor protection in due course. 


\section{P. Bondholders Representative}

The bondholders representative represents the interests of bondholders in the event of default or bankruptcy of the issuer, or other disputes between investors and issuer, and monitors the condition of the issuer and the issued debt securities through their lifecycle. The bondholders representative is required to report to bondholders such status at least every 6 months.

The function of the bondholders representative was introduced in the Prakas on Accreditation of Bondholders Representative published by the SECC in August 2017. As the title of the Prakas suggests, a bondholders representative needs to be accredited with the SECC to carry out said functions. Eligible entities are commercial or custodian banks; securities firms; and securities registrars, securities transfer agents, and paying agents. The term accreditation is used since eligible entities are already licensed by the SECC to undertake corresponding business in the securities market; in the case of banks, they are licensed by NBC.

An accreditation as bondholders representative is valid for 3 years and may be renewed via application to the SECC at least 45 days before the expiry of the current accreditation term.

The appointment of a bondholders representative is mandatory for the issuance of nongovernment (corporate) debt securities via a public offering.

\section{Bondholders Representative Agreement}

The Prakas on Accreditation of Bondholders Representative requires that the issuer and bondholders representative enter into a Bondholders Representative Agreement and also specifies minimum content requirements for such an agreement.

Pursuant to Article 14 of the Prakas, such minimum content includes

i. $\quad$ the contracting parties' identities;

ii. the appointment of the bondholders representative;

iii. the powers, duties, and responsibilities of the bondholders representative;

iv. the fee for the bondholders representative;

v. an indemnification;

vi. terms for the amendment of the agreement;

vii. terms for the termination of the agreement;

viii. the obligations of the bondholders representative after a termination of the agreement; and

ix. terms on claims and responsibility for liabilities.

\section{Obligations of Bondholders Representative}

The bondholders representative will need to discharge its obligations under appointment by the issuer and in accordance with the provisions of the Prakas on Accreditation of Bondholders Representative and the terms set in the Bondholders Representative Agreement.

These obligations include monitoring the status and solvency of the issuer, complying with the terms and conditions of the debt securities, and reporting to bondholders at least every 6 months. The bondholders representative also needs to report any adverse conditions to the SECC. The bondholders representative is required to submit an annual report on its activities and its latest audited financial statement to the SECC within 90 days after the end of a financial year. 
In case of a breach of the terms and conditions of the debt securities, or another event that affects the interests of bondholders, the bondholders representative must inform the bondholders. The bondholders representative will call a bondholders meeting if it deems it necessary or if bondholders representing at least $10 \%$ of the outstanding amount of the debt securities have so requested. Specific provisions for the holding of bondholders meetings are set out in the disclosure document as required under the Prakas.

Under Article 13 of the Prakas on Public Offering of Debt Securities, a bondholders representative is required to establish its own processes and procedures to fulfill its obligations, and create its own code of conduct, including mechanisms to avoid possible conflicts of interest and the timely disclosure of relevant information to bondholders and the SECC.

An accredited entity is not allowed to act as a bondholders representative if the same entity provides other services to the issuer, such as in the capacity of underwriter or guarantor, or has certain capital affiliations with the issuer.

\section{Q. Bankruptcy and Insolvency Provisions}

The Law on Bankruptcy and Insolvency came into effect on 8 December 2007 and was designed to provide collective, orderly, and fair satisfaction of creditor claims from debtor properties and, where appropriate, the rehabilitation of the debtor's business. The Law on Bankruptcy and Insolvency, 2007 applies to the assets of all individuals and legal entities conducting business in Cambodia. ${ }^{26}$

Bankruptcy and insolvency provisions and procedures related specifically to the issuance and servicing of debt securities are expected to evolve in time in line with the development of the Cambodian bond market.

The SECC is in the process of drafting the Anukret on Rehabilitation and Liquidation in the Securities Sector, which is expected to be ready for publication by the end of 2017.

\section{R. Event of Default}

The Prakas on Accreditation of Bondholders Representative includes a definition of default. According to Article 2.1 of the Prakas, "[d]efault refers to any events that cause the issuer to be unable to fulfill the debt payment obligation including principle and/or interest as prescribed in the terms and conditions of the debt securities."

In addition, the Prakas on the Public Offering of Debt Securities prescribed that definitions of possible events of default are to be included in the disclosure document provided to potential investors at the time of the public offering.

In the event of default, the bondholders representative is required to notify the bondholders and also report the event to the SECC.

\footnotetext{
${ }^{26}$ Statement taken from United States Department of State. 2015. Investment Climate StatementCambodia. http://www.state.gov/e/eb/rls/othr/ics/2015/241508.htm
} 


\section{Bond and Note Transactions and Trading Market Infrastructure}

\section{A. Overview}

At present, the Cambodian bond market is in a state of preparation. The GDNT of the MEF is looking into issuing government bonds in the near future and has begun the necessary organizational and legislative preparations toward that goal.

With the CSX operating since 2012 and the NBC trading NCDs with its bank constituents in an interbank money market since 2013, some of a typical market's securities trading infrastructure already exists and could be utilized for the trading of bonds once their issuance commences.

As such, information on existing infrastructure and practices is provided as a matter of reference only. The Cambodia Bond Market Guide will be updated with information specific to debt securities and other subjects once the corporate bond market has been established by the SECC and the proposed Anukret on government securities issuance has been published by the MEF.

\section{B. Permitted Securities Market(s)}

According to the Law on the Issuance and Trading of Non-Government Securities, 2007, the trading of securities in Cambodia may only be carried out in an SECCpermitted securities market with a securities market operator. While the Law on the Issuance and Trading of Non-Government Securities, 2007 contains in-principle provisions for an over-the-counter (OTC) market, the one permitted market for securities trading at present is the CSX.

Each permitted securities market will also have to appoint a securities clearing and settlement operator and a securities depository operator licensed by the SECC. The CSX holds all these licenses for the exchange market.

\section{Trading on the Cambodia Securities Exchange}

The CSX was incorporated in 2010, received its licence to operate in 2011, and began trading operations in April 2012. The CSX is a joint venture between the Government of Cambodia (represented by the MEF) and Korea Exchange, with capital holdings of $55 \%$ and $45 \%$, respectively. The CSX holds licenses for the operation of a securities market as well as clearing and settlement and depository functions.

The CSX has 10 member firms and 5 participants. ${ }^{27}$ Members consist of securities underwriters (6), securities dealers (1), and securities brokers (3). (See also Chapter II.J for further details.) The term participant is used for cash settlement agents, securities registrars, and transfer agents.

\footnotetext{
${ }^{27}$ Please refer to the CSX website at http://www.csX.com.kh/en/member/members.jsp?MNCD=5010
} 
The SECC last issued Prakas representing amendments to the Operating Rules for the CSX in November 2014 and the CSX Listing Rules in September 2015. The Operating Rules include the Clearing and Settlement Rules and the Securities Depository Operating Rules, and have been amended a few times. The rules are all available in English as PDF files from the CSX website. ${ }^{28}$ As a result of the introduction of the regulatory framework for corporate bonds by the SECC in August 2017 , the CSX will revise its rules accordingly. The new versions of these rules were expected to be published by early 2018 .

Since its inception, the CSX has been looking to define operational procedures and processes for both equities and debt securities. Its trading infrastructure and related systems have been adopted from a platform provided by Korea Exchange, which caters to both equity and debt securities trading and clearing in the Republic of Korea. Korea Exchange is one of the few exchanges in ASEAN +3 with significant bond trading volume.

At the end of June 2017, the CSX was trading the stock of five listed companies. These listed companies are shown below in the sequence of their listing on the CSX:

i. Phnom Penh Water Supply Authority under the symbol PWSA,

ii. Grand Twins International (Cambodia) Plc. under the symbol GTI, iii. Phnom Penh Autonomous Port under the symbol PPAP,

iv. Phnom Penh SEZ Plc. under the symbol PPSP, and

v. Sihanoukville Autonomous Port under the symbol PAS.

Following the publication of the regulatory framework for the corporate bond market in August 2017 (see also Chapter II.E), the issuance and subsequent listing and trading of debt securities on the CSX is envisaged to commence after the corresponding changes to CSX rules, which the SECC will then promulgate in the form of appendixes to the relevant Prakas.

Trading on the CSX occurs Mondays through Fridays, excluding nontrading holidays, from the opening session, during which orders may be received, at 8 a.m., until the closing session starting at 11 a.m. (Table 4.1).

Table 4.1: Cambodia Securities Exchange-Trading Hours

\begin{tabular}{|l|c|c|}
\hline Session & Start Time & End Time \\
\hline Opening Session & 8 a.m. & 9 a.m. \\
\hline Continuous Trading Session & 9 a.m. & 11 a.m. \\
\hline Closing Session & 11 a.m. & $11: 30$ a.m. \\
\hline
\end{tabular}

Source: Cambodia Securities Exchange. http://csx.com.kh/operation/market/listPosts.do?MNCD=3020

\section{Plans for Negotiated Segment on the Cambodia Securities Exchange}

In addition to its traditional exchange trading, the CSX has been preparing the functionality for a negotiated segment, known as the Negotiated Trading Method, on its market. This segment will allow CSX members to negotiate directly with other members on the price of listed securities. This practice is similar to the actions in an OTC market and may be applied to trades in debt securities in future. The proposed segment would be subject to approval from the SECC.

${ }^{28}$ See http://csx.com.kh/laws/rules/listPosts.do?MNCD=2050 
In order to facilitate the interaction in the negotiated segment on the CSX, the exchange is looking at creating a separate web-based bond platform that would allow Qualified Investors, including banks and other financial institutions and institutional investors, to participate, seek, and negotiate with counterparties by themselves, provided that the resulting trades are executed by any securities firm who is a CSX member.

\section{Trade Reporting}

The mandatory reporting of debt securities transactions is not yet applicable in Cambodia.

Trades executed on the CSX are captured in the CSX trading system and are reported on its trading platform by default. Executed trades are also reported on the CSX website for the general reference of the public.

\section{Market Monitoring}

The CSX carries out market monitoring of the trading of securities on its market. The CSX refers any detected suspicious breaches of rules to the SECC for investigation, enforcement, and/or prosecution.

\section{E. Information on Securities}

\section{Cambodia Securities Exchange}

The CSX provides comprehensive information on the securities traded on its markets-both on the Main Board and the Growth Board-to the public via the CSX website. In addition to securities transactions data, including trading volume and pricing, the CSX also provides comprehensive information on the listed companies, including their periodic reports and disclosure information. The CSX website also carries material for investor education, in the form of downloadable leaflets on individual products, and the relevant guidelines issued by the SECC, as well as news on the listed companies and their securities and market-relevant publications (Figure 4.1). 
Figure 4.1: Information on the Cambodia Securities Exchange Website

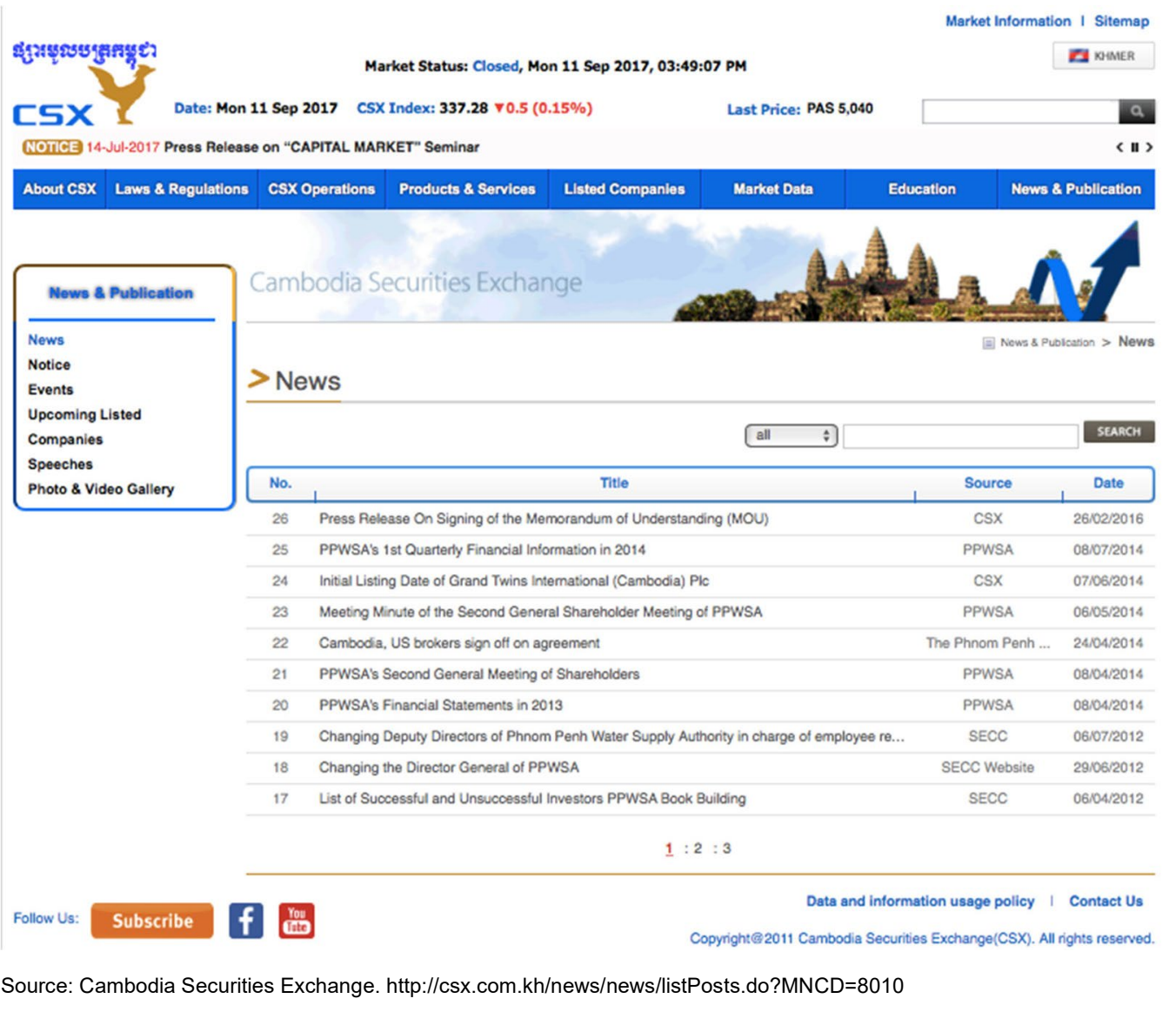

\section{National Bank of Cambodia}

The NBC publishes information on the concept of and procedures for NCDs on its website, including arguments for investment in NCDs, their potential risks, and their usability in the interbank money market. ${ }^{29}$ 


\section{Description of the Securities Settlement System}

This chapter, as included in the original ASEAN+3 Bond Market Guides published in 2012, has been discontinued in favor of a more comprehensive and updated description in the Phase 2 Report of ABMF Sub-Forum 2 (SF2), Information on Transaction Flows and Settlement Infrastructures, dated 13 June 2014.

The SF2 Phase 2 report contains information on the post-trade features of the Cambodian bond market, its market infrastructure and settlement systems, interest payment and redemption practices, as well as market and message standards (pp. 157-65). In addition, the SF2 Phase 2 report contains detailed infrastructure and transaction flow diagrams for Cambodia (pp. 449-63).

The SF2 report is available at www.asianbondsonline.adb.org as well as through a number of mirror sites. ${ }^{30}$

${ }^{30}$ See http://www.adb.org/publications/asean3-information-transaction-flows-and-settlement-infrastructures 


\section{Bond Market Costs and Taxation}

This chapter details the typical costs incurred by issuers and investors in the Cambodian market to the extent that such costs are already known during the current development phase of the Cambodian market.

For ease of reference, the descriptions of the types of costs are given in the context of the actions to be taken by issuers or investors (as explained in this document) and follow the typical life cycle of debt securities.

\section{A. Costs Associated with Securities Issuance}

\section{Application for Issuance Approval from the Securities and Exchange Commission of Cambodia (Mandatory)}

Pursuant to the Law on the Issuance and Trading of Non-Government Securities, 2007, the issuance of securities other than government bonds in the Cambodian market requires the approval of the SECC. This includes the public offering and private placement of debt securities.

The SECC levies an application fee for the review and approval process, payable at the time of submission of the application as well as in case of any resubmission of amendments to the application or supporting documents, or the extension of a registered disclosure document. The fees are not refundable in the case of an unsuccessful application or reregistration.

\section{a. Application Fee}

When intending to offer debt securities to the public, the issuer is required to pay an application fee of KHR12 million for the review and registration of the application and disclosure document. In the event of a second and subsequent offer by the same issuer, the fee levied is KHR8 million.

\section{b. Fee for Replacement or Additional Disclosure Documents}

In the event that the issuer wishes to replace a registered disclosure document or to register additional disclosure documents, a fee of KHR1.1 million for an initial public offering and KHR800,000 for any additional public offering is required for the review and registration of these documents.

\section{c. Fee for Reregistration of Expired Disclosure Documents}

In the event that an issuer wishes to reregister a disclosure document already expired, the SECC stipulates payments of KHR6 million and KHR4 million for an initial public offering and any additional public offering, respectively. 


\section{Underwriter Fee (Mandatory for Public Offering)}

The issuance of corporate debt securities in the Cambodian market via a public offering requires the appointment of an underwriter. Depending on the type and size of the offer, the issuer may require the services of multiple underwriters to place the securities with the targeted investors or to distribute the issuance widely to retail or general investors.

While the underwriter is expected to support the compilation of issuance documentation and the disclosure document, the issuer remains responsible for the submission of applications, disclosure documents, and supporting information to the relevant regulatory authorities. The underwriter will be responsible for its own statements and warranties given in documentation or applications.

An underwriter will charge a fee that is typically commensurate with the effort and risk of taking over part or all of a debt securities issue from the issuer and which may be subject to negotiations between issuer and underwriter.

\section{Securities Registrar and Transfer Agent Fees (Mandatory)}

In the Cambodian market, issuers have to appoint a registered securities registrar and transfer agent (please see Chapter III.M for details and conditions).

The securities registrar and transfer agent is remunerated for its services, here the initial creation and support for distribution of a debt securities issue, based on negotiations with the issuer or a market-typical fee once such practice is more established. In the case of debt securities, the securities registrar and transfer agent will also function as the paying agent for interest and redemption payments, which will be factored into the fee arrangement.

\section{Cambodia Securities Exchange Deposit Fee (Mandatory)}

The CSX also acts as the depository for securities traded on its platform. Equities to be listed and traded on the CSX are expected to be deposited into the CSX Depository for a fee, which will follow the prevailing CSX fee schedule.

The deposit fee is charged for every day of the initial public offering procedure between the actual deposit of the securities to be listed and the effective listing date; market practice expects the duration for which deposit fee is chargeable to be about 1 month. The fee rate is KHR20 for every KHR10 million deposited, and the maximum fee is KHR120,000 per day.

\section{B. Costs for Listing of Securities}

At present, only equities are listed on the CSX. The listing fee(s) follow the prevailing CSX fee schedule approved by the SECC.

For a debt securities listing, a listed entity shall pay a listing fee to the CSX equal to KHR2 million or $0.1 \%$ of the total issuance amount, whichever is larger, based on the price of the public offering and up to a maximum of KHR10 million. In addition, the listed entity shall pay an annual listing fee to the CSX of KHR500,000.

The listing of securities also carries tax incentives for the issuing company and investors. Please see section $\mathrm{G}$ for details. 


\section{Ongoing Costs for Issuers of Securities}

A number of charges are applicable for the issuers of securities in the Cambodian market. Once the issuance of debt securities commences, service provision to issuers and the corresponding service charges are expected to evolve in line with the envisaged development of the corporate bond market.

\section{Securities Registrar and Transfer Agent Fee (Mandatory)}

The appointed securities registrar and transfer agent (see also section A.3) will charge a fee for the provision of its service throughout the lifecycle of the (debt) securities. The transfer agent fee may depend on the size of the issue, frequency of transactions, and other factors.

At the same time, it is possible that the securities registrar and transfer agent may also act as the paying agent, carrying out work related to interest payments and redemptions for debt securities for which a separate fee is expected to be charged.

\section{Costs for Deposit and Withdrawal of Securities}

The Law on the Issuance and Trading of Non-Government Securities, 2007 allows securities to be issued and kept in both physical and electronic form. In practice, the issued stock of listed companies are kept in the CSX Depository only in electronic form. Hence, the actual deposit or withdrawal of individual securities lots by investors is unlikely. This is also expected to apply for future listings of debt securities on the CSX.

\section{E. Costs Associated with Securities Trading}

The present permitted securities market in Cambodia is the exchange market on the CSX. Market regulations prescribe the involvement of licensed securities brokers in the trading of securities for investors unless they are trading for their own account (i.e., as securities dealers).

\section{Brokerage Fees}

Licensed securities brokers carry out securities trading on behalf of their customers and charge a brokerage fee or commission in line with market practice.

\section{F. Taxation Framework and Requirements}

The General Department of Taxation of the MEF collects tax revenues and provides taxpayer and education services in Cambodia, acting as an agent of the Government of Cambodia. ${ }^{31}$

\footnotetext{
${ }^{31}$ See http://www.tax.gov.kh/en/
} 
Table 6.1: Duties and Taxes on Securities in Cambodia

\begin{tabular}{|c|c|c|}
\hline Duties and Tax & Type of Bond & Tax Rate \\
\hline \multirow{2}{*}{$\begin{array}{l}\text { Corporate Income Tax } \\
\text { (Profit Tax) }\end{array}$} & Government & n.a. \\
\hline & Corporate & $\begin{array}{l}20 \% \text { (standard rate), or } 10 \% \text { with tax } \\
\text { incentive for listed issuers }\end{array}$ \\
\hline \multirow{3}{*}{ Withholding Tax } & Government & Exempt \\
\hline & \multirow{2}{*}{ Corporate } & Residents: 0\% \\
\hline & & $\begin{array}{l}\text { Nonresidents: } 14 \% \text { (standard rate), or } 7 \% \text { on } \\
\text { interest from securities from listed issuers }\end{array}$ \\
\hline \multirow{2}{*}{ Capital Gains Tax } & Government & n.a. \\
\hline & Corporate & $0 \%$ \\
\hline \multirow{2}{*}{ Stamp Duty } & Government & \multirow{2}{*}{$0 \%$. } \\
\hline & Corporate & \\
\hline VAT & Universal & $0 \%$ \\
\hline
\end{tabular}

Residents and nonresidents investing in Cambodia are subject to duties and taxes on securities as summarized in Table 6.1. The applicability of and practices for the relevant duties and taxes are explained in the subsequent sections.

Taxation applicable specifically to debt securities may need to be confirmed once the issuance, listing, and trading of debt securities commences. At the same time, a number of tax provisions and tax incentives are, in fact, agnostic as to the type of underlying securities or revenue sources.

As general guidance, where taxation does not specifically include the treatment of debt securities, the taxation applicable to equities is mentioned here.

\section{Profits Tax}

The standard corporate income tax rate is $20 \%$ (standard rate). Under available tax incentives (see section $\mathrm{H}$ ), a concessionary rate of $10 \%$ applies for the profit of a company listed on the CSX during 3 years of the tax incentive period.

\section{Withholding Tax}

The typical withholding tax rate on payments made to a physical person or an enterprise, except for interest paid to a domestic bank or savings institution, is $15 \%$. However, residents are exempt from withholding tax on the interest from debt securities and instead are subject to income tax. The standard withholding tax rate on interest from debt securities for nonresidents is $14 \%$. However, nonresidents may reduce the withholding tax rate to $7 \%$ when investing in debt instruments from issuers listed on the CSX (see section $\mathrm{H}$ ).

\section{Capital Gains Tax}


Capital gains tax is not applicable for investments in government securities. For corporate bonds, the capital gains tax is presently zero-rated.

\section{Stamp Duty}

At present, no stamp duty is levied on transactions in the securities sector.

5. Value Added Tax

The value-added tax is presently zero-rated for the securities sector.

\section{Double Taxation Agreements}

To date, Cambodia has not entered into any Double Tax Agreements with other countries. As such, no special considerations from the perspective of nonresident investors currently exist.

\section{Tax Exemption for Nonresident Investors}

While tax incentives exist for investors in the Cambodian securities market (see section $\mathrm{H}$ for details), there are no incentives aimed specifically at nonresident investors. The tax incentive scheme is applicable to all investors, regardless of residence status.

\section{G. Tax Incentives}

The Government of Cambodia passed the Anukret on Tax Incentives in the Securities Sector (No. 70 ANKR BK) in April 2011, with the provisions rolled over in 2015. The Anukret will be renewed by early 2018 .

The tax incentives under this sub-decree are available to nonresident investors, as well as to issuers of equities and debt securities, and apply to all types of securities; government securities and debt securities are specifically mentioned as included. However, the text of the sub-decree also stipulates that these securities need to be listed on a permitted securities market such as the CSX.

The sub-decree states that issuers and investors need to submit a form to the General Department of Taxation, via the SECC, to receive a grant of the incentives.

More information on these tax incentives is available from the CSX website. ${ }^{32}$

\section{Incentives to Issuers}

Under Article 4 of the sub-decree, issuers that list their securities on the CSX are able to claim a $50 \%$ reduction of the tax on profit to be paid for a period of 3 years.

In addition, the General Department of Taxation has issued an additional Prakas providing for tax incentives for companies to issue and list securities on the CSX. These incentives include the ability to postpone the monthly prepayment of tax on profit to the end of the financial year in addition to any concessions on the actual rate of tax on profit payable by these issuers.

\section{Incentives to Investors}

\footnotetext{
${ }^{32}$ See http://csx.com.kh/en/product/Anukret_on_Tax_Incentive_in_Securities_Sector_English.pdf
} 
In turn, nonresident investors in listed securities are able to claim a $50 \%$ reduction of the withholding tax on dividends or interest for a period of 3 years (please see Chapter III.N for details), with the timeframe starting with the launching of the securities market (Article 5 of the relevant Prakas). In the case of debt securities, investors are expected to be able to avail this incentive once the issuance of debt securities commences. 


\section{Market Size and Statistics}

The original ASEAN+3 Bond Market Guide was published in April 2012 and included several pages of bond market statistics for the published economies, including historical data such as bond holdings, bondholder distribution, outstanding amounts, and trading volumes. Not surprisingly, this data became stale soon after publication.

Since the ASEAN+3 Bond Market Guide is most likely to be updated only on a biennial basis, it is not the best channel for the dissemination of market statistics. Hence, a chapter comprising bond market statistics has been discontinued and replaced with a list of recommended sources for detailed, accurate, and current information sources on the Cambodian bond market. These sources are listed below in alphabetical order.

- $\quad$ AsianBondsOnline (an ASEAN+3 initiative lead by ADB)

https://www.asianbondsonline.adb.org/cambodia.php

- Market-at-a-Glance

- News

- Cambodia Securities Exchange

http://csx.com.kh/data/index/daily.do?MNCD=60101

- Daily closing index

- Top 5 member performance (daily)

- End-of-Day data (daily)

- $\quad$ National Bank of Cambodia

http://www.nbc.org.kh/english/economic_research/monetary_and_financial _statistics_data.php

- Monetary and financial statistics data 


\section{Presence of an Islamic Bond Market}

At present, there is no Islamic bond market in Cambodia. 


\section{Cambodian Bond Market Challenges and Opportunities}

This chapter discusses some of the real and perceived challenges facing the Cambodian bond and securities market, its policy bodies and regulatory authorities, as well as its participants, including potential issuers and investors that are nonresidents. This chapter also aims to describe the possible mitigating factors or market developments that could address these challenges in an appropriate manner.

\section{A. Challenges in the Cambodian Bond Market}

\section{Absence of Government Bonds and Bond Yield Curve}

The absence of government securities in Cambodia and the corresponding absence of a benchmark yield curve presents a challenge for any potential issuer-and their underwriters - to adequately determine the level of interest rates for issuances in the corporate bond market (see section B.2). As such, issuers will have to proceed carefully with their initial issuances in order to determine a suitable level of interest rates in comparison to bank loans, which are currently the prevalent means of financing for corporates. This, in conjunction with the expected level of disclosure for debt securities issuance-a standard that many issuers will take time to learn —may result in a slow start for the bond market's operation.

\section{Need for Real-Time Gross Settlement System}

Having an RTGS system is a vital infrastructure building block for any financial market. Particularly for a bond market, where transactions sizes are typically recorded in the millions of dollars or the equivalent in local currency, the need for a high-value payment system, typically administered by the central bank, is very important.

The NBC is working on the development of an RTGS system.

\section{Capacity Building}

As is a typical challenge in a nascent market, capacity building takes center stage. In Cambodia, this includes getting companies to develop a corporate governance culture comparable to other markets and in line with investor expectations (see also item 4).

The SECC is also seeking to license more market participants, including securities firms, and to accredit custodian banks, CRAs, and bondholders representatives to educate the public at large and to develop market knowledge that will lead to reliable practices and standards. For that purpose, the SECC began issuing dedicated Prakas for the accreditation of bondholders representatives and CRAs in August 2017 as part of the regulatory framework for the corporate bond market. 
In turn, securities underwriters can nurture companies that are able and willing to issue securities and support the development of a corporate governance culture through their actions as well as those of issuers.

\section{Corporate Governance as a Milestone to Securities Issuance}

Similar to other nascent markets, a key objective will be for more domestic public companies to become listed companies (through equity listings) and/or to issue and list their future debt securities on the CSX. This process involves creating the discipline to disclose relevant information and the ability to use such discipline in the issuance of securities and their listing on CSX. This includes the need to produce and maintain auditable results, including financial statements comparable to other markets, so that investors, domestic and nonresident, can assess a company's performance. This process will also involve training intermediaries in servicing these public companies in an appropriate manner, including underwriters, auditors, and law firms to maintain, support, and enforce good corporate governance.

To provide guidance on the level of disclosure expected for the issuance of debt securities, the SECC has included substantial provisions on disclosure requirements in its Prakas on Public Offering of Debt Securities published in August 2017.

\section{Conversion to Recognized Accounting Standards}

Among the quantitative requirements in the CSX Listing Rules, a company must provide at least 2 years of audited financial reports prepared by an accredited international accounting firm approved by the Cambodian government to be eligible for listing. ${ }^{33}$ This may be a challenge for potential issuers.

In the transition from public companies to listed companies, such potential issuers will need to acquire the ability to produce financial reporting in the formats adopted by the International Accounting Standards Board, referred to as International Financial Reporting Standards (IFRS). The National Accounting Council of Cambodia fully adopted IFRS Standards and IFRS Standards for SMEs through a Prakas issued by the MEF in January 2009. ${ }^{34}$ Accordingly, issuers whose securities are traded in a public market - the CSX in Cambodia-were required to adopt IFRS Standards with effect from accounting periods starting on 1 January 2012. For commercial banks and microfinance institutions, the implementation of IFRS Standards became mandatory with effect from 1 January 2016.

At the same time, the ability to produce financial reports in IFRS format of listed issuers or typical issuers of debt securities in future, such as commercial banks, will make these securities principally accessible for both domestic and nonresident investors who may only invest in assets that provide international standards reporting. Moreover, these securities will also be able to be assessed for credit rating and investment analysis as a result of comparable reporting formats.

\section{Transparency of Tax Processes}

Equally significant to investors is the clarity of the taxation concepts and practices applied in the capital market, with a particular focus on capital gains and withholding taxes. While an Anukret on Tax Incentives in the Securities Sector was issued in 2011 and listed securities (referring to equities only) are exempt from withholding tax at present, the applicability of these concessions to debt securities once issued needs to

\footnotetext{
${ }^{33}$ For a complete list of CSX Main Board listing eligibility criteria, please see http://csx.com.kh/en/product/mainboard.jsp?MNCD=40302

${ }^{34}$ See http://www.ifrs.org/Use-around-the-world/Documents/Jurisdiction-profiles/Cambodia-IFRS-Profile.pdf
} 
be either confirmed or tested. Until that has occurred, institutional investors may take a wait-and-see approach.

\section{B. Opportunities in the Cambodian Bond Market}

\section{General Policy and Regulatory Environment in Cambodia}

Since the global financial crisis, regulators around the world have been strengthening laws and regulations in capital and financial markets. Of particular interest have been banking regulations and the focus on risk-weighted capital. For financial markets, this includes limits on what banks can or are willing to lend, to whom, and under what circumstances. A number of these regulatory initiatives may, in consequence, lead to a rebalancing of funding options for the corporate sector from bank loans to capital markets.

This overall development might positively influence potential domestic issuers to consider raising funds via bond or note issuance, and to diversify their debt portfolio. Such increased interest, coupled with a broader and deeper investor base (see also item 4), might also have a beneficial impact on funding costs in Cambodia.

Just as these developments filter into individual markets in ASEAN+3, the SECC has begun to further define the regulatory framework for a bond market as an alternative means for company funding (see also item 2). At the same time, as the bond market in Cambodia is in a nascent stage of development, the SECC and other policy bodies and regulatory authorities have the unique opportunity to set objectives and implement regulations that seek to avoid potential pitfalls and focus on measures that have proven successful and practical elsewhere, adapting such measures to the needs of the Cambodian economy. An example is the introduction of a Qualified Investor regime in August 2016, using a clear and practical definition of a professional investor concept, in preparation for a professional market to international standards at a later date.

The availability of all relevant laws (Kram), regulations (Anukret and Prakas), and rules (e.g., CSX Listing Rules) in English through the websites of the CSX and the SECC greatly adds to transparency and the level of information available on the Cambodian securities market at large. As new regulations are published, the regulatory framework also continues to increasingly adopt international standards with regard to terminology and practices in the bond market.

\section{Regulatory Framework for the Corporate Bond Market}

In August 2017, the SECC introduced the necessary regulatory framework for the corporate bond market in Cambodia through the publication of a number of new Prakas (see also Chapter II.C). Each Prakas focused on a specific aspect of the market, from issuance and approval processes for public offerings to CRAs (and their requirements) and a bondholders representative function. For more details, please see the corresponding sections in Chapter III.

This framework created a new asset class in the Cambodian market and paves the way for the introduction of government securities beginning in 2019. This new asset class can address pent-up demand among the typical bond market investor universe (see item 4). 


\section{Listing of Debt Securities on the CSX is Principally Possible}

The regulatory framework for corporate bonds introduced by the SECC in August 2017 also included the ability to list and trade nongovernment debt securities on the CSX. With the CSX exchange platform and processes being provided by joint venture partner Korea Exchange, which is experienced in debt securities trading and processing on its version of said platform, the market expects issuers to be able to list debt securities within a short timeframe. This would add visibility and transparency to bond issuance, listing, and trading practices in the Cambodian market.

\section{Pent-Up Demand among Domestic Investors}

Chapter III.M of the Cambodia Bond Market Guide lists the typical investor types in a bond market and the potential for such investors in Cambodia. Chief among them are insurance companies and pension or provident funds, which, based on their prudential mandates, are required to seek fixed-income instruments to generate a steady return. At the same time, the Law on the Issuance and Trading of Non-Government Securities, 2007 and supplementary regulations introduced collective investment schemes (e.g., unit trusts and mutual funds), which are also expected to invest in debt securities and, in turn, offer ordinary investors access to the bond market.

In the absence of a bond market, these investor types were limited to bank deposits at lower returns. They had no opportunity to diversify their portfolios, as is generally expected of them. The advent of the corporate bond market, with government securities to follow soon after, will offer these investor types suitable returns on, and better diversification of, their investments. 


\section{Recent Developments and Future Direction}

\section{A. Recent Major Developments}

Recent major developments are considered those that occurred or have been announced in the Cambodian market since the first publication of the ASEAN+3 Bond Market Guide for selected economies in April 2012.

\section{Introduction of Corporate Bond Regulatory Framework}

The SECC introduced a framework for the issuance of nongovernment debt securities in August 2017. The framework consists of regulations for the public offering of debt securities and accreditation of CRAs and bondholders representatives, as well as the corresponding listing and market operation rules and disclosure requirements of the CSX. More details of the new framework can be found in the individual sections of the Cambodian Bond Market Guide.

\section{Establishment of a Professional Investor Concept}

In August 2016, the SECC issued the Prakas on Qualified Investors in the Securities Sector, thereby introducing a professional investor concept to the market and defining the categories of Institutional Investor and High Net-Worth Investor. Specific institutions are defined in the Prakas as Institutional Investors (e.g., NBC), while other entities are accorded this status based on their function (e.g., banks), or by having obtained a specific license to participate in the securities market. In turn, High NetWorth Investors need to fulfill certain qualifying criteria to be registered as such.

The obligation to register and maintain status as a Qualified Investor rests with securities firms, who must confirm an investor's eligibility based on supporting documentation. Securities firms also must provide a list of Qualified Investors to the SECC on a periodic basis.

\section{Introduction of Negotiable Certificates of Deposit}

In 2013, the NBC introduced NCDs to the marketplace after several years of deliberation and testing.

The NBC issues NCDs directly to banks and other financial institutions, and trades NCDs bilaterally with the constituent participants of the national clearing system. The NBC initiative to issue NCDs was aimed at creating an interbank market and providing an instrument for constituents to be able to manage liquidity and minimum reserve requirements (further details are available in Chapter III.E).

Banks participating in the NBC clearing system can now also trade NCDs with each other (see Chapter IV for more details). 


\section{B. Future Direction}

While the bond market in Cambodia is at a nascent stage of development, clear plans toward the issuance of government securities and the establishment of a corporate bond market exist.

In line with the focus of the policy bodies and regulatory authorities on developing the bond market, much change is expected in the 12-18 months following the publication of the Cambodia Bond Market Guide. The MEF has updated the FSDS with plannedor envisaged developments for 2016-2025 (see also Chapter I.B). These developments and the implementation of individual polices, directives, and practices are expected to comprehensively address the existing challenges in the bond market in Cambodia (see also Chapter IX).

\section{Preparation of the Supporting Regulations and Accreditation of} Market Participants for the Corporate Bond Market

Following the introduction of the initial set of Prakas for the corporate bond market in August 2017, the SECC is now preparing the supporting regulations, including the form and format of the disclosure document and the application form for issuers wishing to offer a corporate bond to the public. In addition, the SECC is also preparing the stated accreditation for CRAs and bondholders representatives.

The relevant CSX operating rules-such as those for debt securities listing, market operation, clearing and settlement, and depository functions-are expected to be available by early 2018 .

\section{Introduction of Custodian Concept}

In conjunction with the introduction of the corporate bond regulatory framework, the SECC is putting the finishing touches on the introduction of a custodian concept in the Cambodian bond market. At present, investor assets are held at the CSX Depository through CSX members, all of which are brokers, executing investor trade orders. The introduction of a third-party custodian function is expected to attract domestic and foreign institutional investors, which have specific requirements for the segregation and protection of their assets under prudential regulations.

At the time of the compilation of the Bond Market Guide, the draft Prakas on Accreditation of Custodians was in the public consultation stage.

\section{Utilization of the Qualified Investors Concept}

The SECC introduced the Qualified Investor concept to the market in August2016. It defines a class of professional investors and ringfences them from ordinary or general investors for whom the SECC will pursue maximum protection within its bond market framework. The Qualified Investor concept gives rise to the expectation that the SECC may introduce a market segment, aimed solely at professional investors, that will include provisions for the use of private placement as an issuance method.

At the same time, the ability to utilize an existing professional investor concept in the context of the corporate bond framework allows the SECC to position Cambodia as a potential market for the issuance of bonds and notes under the ASEAN+3 MultiCurrency Bond Issuance Framework. 
4. Regulations on the Issuance of Government Securities

The Law on Government Securities, 2007 will provide the foundation for the issuance of government securities, which is envisaged to commence in 2019. To make full use of the provisions of the law, an Anukret would have to be promulgated by the MEF before any actual bond issuance to set the stage for the introduction of a government bond market, its features, and expected participants.

A corresponding Anukret is presently in the drafting stage, indicating that the GDNT's plans for the development of the sovereign debt market are on track. 


\section{Appendix 1 Practical References}

For easy access to further information about the market features described in the Cambodia Bond Market Guide-including information on the policy bodies, regulatory authorities, and securities market-related institutions-interested parties are encouraged to utilize the following links (all websites available in English):

AsianBondsOnline (Asian Development Bank)

http://asianbondsonline.adb.org/cambodia.php

Cambodia Securities Exchange

http://www.csx.com.kh/main.do

Council for the Development of Cambodia

http://www.cambodiainvestment.gov.kh

General Department of Financial Industry, Ministry of Economy and Finance http://gdfi.mef.gov.kh

General Department of National Treasury

http://www.treasury.gov.kh

General Department of Taxation, Ministry of Economy and Finance http://www.tax.gov.kh/en/

Ministry of Economy and Finance (partly in English)

http://www.mef.gov.kh

National Bank of Cambodia

http://www.nbc.org.kh/english/index.php

National Bank of Cambodia-Negotiable Certificates of Deposit Overview http://www.nbc.org.kh/english/monetary_policy/ncds_overview.php

Government of Cambodia—Financial Sector Development Strategy, 2011-2020 (Asian Development Bank publication)

http://adb.org/sites/default/files/pub/2012/financial-sector-development-strategy-2011-

2020.pdf

Securities and Exchange Commission of Cambodia

http://www.secc.gov.kh/english/

World Bank-Cambodia

http://www.worldbank.org/en/country/cambodia/overview 


\section{Appendix 2 List of Laws and Regulations}

For ease of reference, a list of the sub-decrees (Anukret), official declarations (Prakas), and guidelines relevant for the bond market in Cambodia are listed below, starting with the most recent publication in each category.

\section{Kram (Laws)}

\begin{tabular}{|l|l|c|}
\hline Designation & Title & $\begin{array}{c}\text { Last } \\
\text { Issued }\end{array}$ \\
\hline No. NS/RKM/1007/028 & $\begin{array}{l}\text { Law on Issuance and Trading of Non-Government } \\
\text { Securities }\end{array}$ & 2007 \\
\hline No. NS/RKM/0107/001 & Law on Government Securities & 2007 \\
\hline
\end{tabular}

The above laws, or Kram, are available on the website of the Securities and Exchange Commission of Cambodia at http://www.secc.gov.kh/english/m21.php?pn=3

\section{Anukret (Sub-decrees)}

\begin{tabular}{|l|l|c|}
\hline Designation & Title & $\begin{array}{l}\text { Last } \\
\text { Issued }\end{array}$ \\
\hline $\begin{array}{l}\text { No. } 70 \\
\text { ANKR BK }\end{array}$ & Anukret on Tax Incentives in the Securities Sector & 2015 \\
\hline $\begin{array}{l}\text { No. 54 } \\
\text { ANKR BK }\end{array}$ & $\begin{array}{l}\text { Anukret on the Implementation of the Law on Issuance and Trading } \\
\text { of Non-Government Securities }\end{array}$ & 2009 \\
\hline $\begin{array}{l}\text { No. 396 } \\
\text { ANKR TT }\end{array}$ & $\begin{array}{l}\text { Anukret on the Appointment of the Composition of the Securities } \\
\text { and Exchange Commission of Cambodia }\end{array}$ & 2009 \\
\hline $\begin{array}{l}\text { No. 97 } \\
\text { ANKR BK }\end{array}$ & $\begin{array}{l}\text { Anukret on the Conduct and Organization of the Securities and } \\
\text { Exchange Commission of Cambodia }\end{array}$ & 2008 \\
\hline
\end{tabular}

The above Anukret are available from the website of the Securities and Exchange Commission of Cambodia at http://www.secc.gov.kh/english/m22.php?pn=3 


\section{Prakas (Official Declarations)}

\begin{tabular}{|c|c|c|}
\hline Designation & Title & $\begin{array}{l}\text { Last } \\
\text { Issued }\end{array}$ \\
\hline $\begin{array}{l}\text { No. } 011 / 17 \\
\text { SECC/Pr.K. }\end{array}$ & Prakas on Accreditation of Credit Rating Agency & 2017 \\
\hline $\begin{array}{l}\text { No. } 010 / 17 \\
\text { SECC/Pr.K. }\end{array}$ & Prakas on Accreditation of Bondholders Representative & 2017 \\
\hline $\begin{array}{l}\text { No. } 009 / 17 \\
\text { SECC/Pr.K. }\end{array}$ & Prakas on Public Offering of Debt Securities & 2017 \\
\hline $\begin{array}{l}\text { No. } 005 / 16 \\
\text { SECC/Pr.K. }\end{array}$ & Prakas on Qualified Investors in the Securities Sector & 2016 \\
\hline $\begin{array}{l}\text { No. } 006 / 15 \\
\text { SECC/Pr.K. }\end{array}$ & Prakas on the Implementation of Listing Rules & 2015 \\
\hline $\begin{array}{l}\text { No. } 008 / 11 \\
\text { SECC/Pr.K. }\end{array}$ & $\begin{array}{l}\text { Prakas on Code of Conduct of Securities Firms and Securities } \\
\text { Representatives }\end{array}$ & 2011 \\
\hline $\begin{array}{l}\text { No. } 006 / 11 \\
\text { SECC/Pr.K. }\end{array}$ & $\begin{array}{l}\text { Prakas on the Implementation of the Operating Rules of the } \\
\text { Securities Market }\end{array}$ & 2011 \\
\hline $\begin{array}{l}\text { No. } 003 / 11 \\
\text { SECC/Pr.K. }\end{array}$ & Prakas on the Implementation of the Membership Rules & 2011 \\
\hline $\begin{array}{l}\text { No. 009/10 } \\
\text { SECC/Pr.K. }\end{array}$ & $\begin{array}{l}\text { Prakas on the Registration of Securities Registrar, Securities } \\
\text { Transfer Agent, and Paying Agent }\end{array}$ & 2010 \\
\hline
\end{tabular}

The above Prakas are available on the website of the Securities and Exchange Commission of Cambodia at http://www.secc.gov.kh/english/m23.php?pn=3

\section{Guidelines}

\begin{tabular}{|l|l|c|}
\hline Designation & Title & $\begin{array}{l}\text { Last } \\
\text { Issued }\end{array}$ \\
\hline $\begin{array}{l}\text { No. 152/14 } \\
\text { SECC/K.N.N. }\end{array}$ & Guidelines on the Mechanism of Receiving Securities Order & 2014 \\
\hline $\begin{array}{l}\text { No. 003/12 } \\
\text { SECC/K.N.N. }\end{array}$ & $\begin{array}{l}\text { Guidelines on the Procedure of Cash Settlement in the } \\
\text { Securities Market }\end{array}$ & 2012 \\
\hline $\begin{array}{l}\text { No. 001/12 } \\
\text { SECC/K.N.N. }\end{array}$ & Guidelines on Granting Investor Identification Number & 2012 \\
\hline
\end{tabular}

The above guidelines are available on the website of the Securities and Exchange Commission of Cambodia at http://www.secc.gov.kh/english/m24.php?pn=3 


\title{
Appendix 3 Glossary of Technical Terms
}

\author{
Applicant Term used for a potential issuer who has filed an application for \\ the issuance of (debt) securities with the SECC \\ Anukret Regulations or rules pursuant to specific laws \\ bondholders \\ representative \\ Term used in Cambodia for the function of representing the \\ Bondholders \\ Representative \\ interests of bondholders in relation to the issuer \\ Agreement \\ Agreement to be entered into between an issuer and bondholders \\ representative \\ exempt \\ securities \\ dealers \\ exempt \\ securities \\ transaction \\ Specific term under the law for individuals or entities not subject to \\ licensing as a securities firm or representative, such as a market \\ operator or insolvency administrator \\ Specific term under the law for securities transactions not subject \\ to licensing as an activity of a securities firm or representative, \\ such as the issuance of government securities \\ High Net- \\ Worth \\ Individual \\ Institutional \\ Investors \\ Investor category under the Qualified Investor concept with \\ specific qualifying criteria \\ Investor category under the Qualified Investor concept with \\ specific legal entities defined \\ Kram \\ Law or decree \\ Prakas \\ over-the- \\ counter \\ Official declarations or notices (from regulatory authorities) that \\ interpret laws and regulations \\ permitted \\ organized trading of unlisted securities \\ securities \\ Term used in laws and regulations for a market approved by the \\ market \\ public \\ company \\ SECC for the trading of securities, including debt securities \\ public \\ Does not denote a listed company as in other markets; instead \\ refers to companies that are not classified as private \\ investors \\ Market-specific term for retail or general investors \\ Qualified \\ Investors \\ Professional investor concept in Cambodia \\ registration \\ Term used to refer to the lodging with, and acceptance by, the \\ SECC of the disclosure document for debt securities
}




$\begin{array}{ll}\begin{array}{l}\text { securities } \\ \text { market } \\ \text { operator }\end{array} & \begin{array}{l}\text { Official term in legislation and regulations for an exchange or } \\ \text { facilitator of an OTC market }\end{array} \\ \begin{array}{l}\text { securities } \\ \text { sector }\end{array} & \text { Official name in Cambodian regulations for the securities market }\end{array}$

Source: ADB consultants for SF1. 


\section{ASEAN+3 Bond Market Guide 2018 Cambodia}

ASEAN+3 Bond Market Guide is a comprehensive explanation of the region's bond markets. It provides information such as the history, legal and regulatory framework, specific characteristics of the market, trading and transaction (including settlement systems), and other relevant information. The Bond Market Guide 2018 for Cambodia is an outcome of the support and contributions of ASEAN+3 Bond Market Forum members and experts, particularly from Cambodia.

\section{About the Asian Development Bank}

ADB's vision is an Asia and Pacific region free of poverty. Its mission is to help its developing member countries reduce poverty and improve the quality of life of their people. Despite the region's many successes, it remains home to a large share of the world's poor. ADB is committed to reducing poverty through inclusive economic growth, environmentally sustainable growth, and regional integration.

Based in Manila, ADB is owned by 67 members, including 48 from the region. Its main instruments for helping its developing member countries are policy dialogue, loans, equity investments, guarantees, grants, and technical assistance.
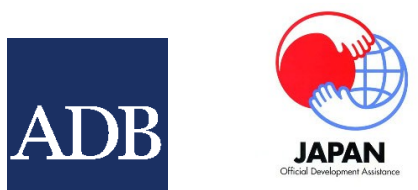